\title{
Kradzież pieniędzy zrzutowych z placówki „Kopyto”. Sprawa karna pchor. Tadeusza Szatkowskiego „Groma” przed Wojskowym Sądem Specjalnym Komendy Głównej Armii Krajowej
}

\begin{abstract}
Abstrakt: Opracowanie dotyczy sprawy karnej, rozpoznanej przez Wojskowy Sąd Specjalny przy Komendzie Głównej AK, przeciw pchor. Tadeuszowi Szatkowskiemu „Gromowi”, żołnierzowi AK z placówki odbioru zrzutów pod Końskimi, oskarżonemu o przywłaszczenie pieniędzy na szkodę Polskich Sił Zbrojnych. Autor omówił materiał stanowiący podstawę przeprowadzenia postępowania karnego oraz wydania wyroku i kwestii związanych z jego niewykonaniem. Podjął próbę prawnokarnej analizy powyższej sprawy oraz wydanego wyroku w odniesieniu zarówno do wymogów formalnoprawnych, jak i słuszności wydanego orzeczenia.
\end{abstract}

Słowa kluczowe: cichociemni, Armia Krajowa, sądownictwo podziemne, Wojskowy Sąd Specjalny, Związek Walki Zbrojnej.

Abstract: The study deals with a criminal case examined by the Special Military Court at the High Command of the Home Army against the Home Army Officer Cadet Tadeusz Szatkowski aka Grom, serving at the post to receive airdrops near Końskie, charged with appropriation of money to the detriment of the Polish armed forces. The author examines the source material on which the criminal case and sentence were based together with questions related to its non-execution. He attempts to make a legal-criminal analysis of the case and the sentence in relation to both formal and legal conditions, and the validity of the sentence.

Keyw ords: "Silent Unseen", Home Army, underground judiciary, Special Military Court, Union of Armed Struggle. 
Wraz z powstaniem w okupowanym kraju Związu Walki Zbrojnej (ZWZ) konieczne stało się utrzymywanie łączności z Rządem RP na uchodźstwie. Stworzone drogi łączności radiowej i łączności kurierów oraz emisariuszy okazały się niewystarczające ${ }^{1}$. W ten bowiem sposób trudno było zapewnić, w miarę stały, dopływ pieniędzy, materiałów wojskowych oraz przeszkolonych żołnierzy do pracy podziemnej w kraju. Pierwszym, który podniósł kwestię przerzutu ludzi i sprzętu metodą zrzutów spadochronowych, był mjr dypl. Włodzimierz Mizgier-Chojnacki². Meldunek w tej sprawie złożył on dowódcy lotnictwa i obrony przeciwlotniczej gen. bryg. Józefowi Zającowi jeszcze we Francji 7 XII 1939 r. Zaproponował w nim również kandydatów na instruktorów ośrodka spadochronowego. Oceny tych propozycji dokonał w piśmie z 14 XII 1939 r. Władysław Tuchułka ${ }^{3}$. Był on sceptycznie nastawiony do pomysłu tworzenia jednostek desantowych. Dostrzegł jednak, że sporadyczne przerzucanie do kraju osób poprzez skok ze spadochronem ma tę zaletę, że wymagałoby jedynie krótkiego, dwutygodniowego przeszkolenia. Dwa tygodnie później, 30 XII 1939 r. kpt. Jan Górski opracował projekt utworzenia drogi powietrznej do pomocy walczacemu krajowi. Pomoc ta winna mieć charakter szybkiej łączności kurierskiej, a przy planowanym powszechnym powstaniu zapewnić drogę przerzutu wyćwiczonych w skokach spadochronowych żołnierzy. Założenia programu szkolenia wojsk spadochronowych opracował $14 \mathrm{~V} 1940 \mathrm{r}$. mjr obs. Lucjan Fijuth ${ }^{4}$. Powyższe koncepcje zyskały akceptację naczelnego wodza gen. Władysława Sikorskiego. W styczniu 1940 r. wojsko dysponowało już 57 osobami przeszkolonymi spadochronowo; grupa ta miała stanowić kadrę ośrodków szkoleniowych ${ }^{5}$. Przystapiono do werbunku ochotników i jesienia 1940 r. przeszkolono pierwszych kilkunastu z nich ${ }^{6}$. W 1940 r. w Anglii podjęto próby stworzenia drogi powietrznej celem pomocy walczącemu krajowi. W instrukcji z 2 XI 1940 r. gen. broni Kazimierz Sosnkowski wskazywał, że przygotowania do nawiązania łączności z krajem przez skoczków spadochronowych dobiegają końca i pierwsze loty najprawdopodobniej zostaną wykonane

${ }^{1}$ Generał Kazimierz Sosnkowski wskazywał płk. Stefanowi Roweckiemu, że do czasu uruchomienia drogi radiowej kurierzy i emisariusze będą podstawowym środkiem łączności dla ZWZ. Por. Instrukcja nr 2 z 16 I 1940 r. dla ob. Rakonia (Grabicy), w: Armia Krajowa $w$ dokumentach 1939-1945, t. I, cz. 1: Wrzesień 1939 - czerwiec 1941, Warszawa 2015, s. 181.

${ }^{2}$ Rocznik oficerski 1939. Stan na dzień 23 marca 1939, red. R. Rybka, K. Stepan, Kraków 2006, s. 287, 477; H.M. Królikowski, O organizacji desantów $i$ wojska spadochronowego w Polsce przed II wojna światowa, ,Szkice Podlaskie” 2000, nr 8, s. 131-132.

${ }^{3}$ Rocznik oficerski 1939..., s. 206, 477.

${ }^{4}$ A. Chmielarz, Koncepcje wykorzystania skoczków spadochronowych na rzecz okupowanego kraju (1939-1940), w: Polskie wojska spadochronowe w II wojnie światowej, red. J. Zuziak, Warszawa 2012, s. 42-44, 47.

${ }^{5}$ Ibidem, s. 46. Jako jeden z pierwszych akces do wojsk spadochronowych zgłosił 8 I $1940 \mathrm{r}$. ppor. Jan Rogowski „Czarka”.

${ }^{6}$ J. Tucholski, Cichociemni, Warszawa 1988, s. 31; G. Hanula, 316, „Zgrupowanie Radosław” 2011, nr 5, s. 145-146. 
w drugiej połowie listopada 1940 r. Od kraju domagano się wskazania miejsc zrzutowisk oraz adresów kontaktowych do odbioru skoczków ${ }^{7}$, co też zostało wkrótce zrealizowane ${ }^{8}$. W odpowiedzi, drogą radiowa, przekazano na Zachód umiejscowienie szeregu zrzutowisk oraz żądane adresy punktów kontaktowych wraz z nazwiskami osób i hasłami dla cichociemnych. Placówki odbioru zrzutów określano różnymi kryptonimami i były one rozlokowane na terenie Generalnego Gubernatorstwa. Między innymi wskazano placówkę zrzutu o kryptonimie „Kopyto” (8 km na północny wschód od Końskich), na której doszło do kradzieży pieniędzy zrzutowych. Funkcjonowanie placówki odbioru zrzutu było określone w instrukcji stanowiącej załącznik nr 2 do instrukcji nr 8 z 22 IX 1941 r. Wskazano w niej szczegółowe zasady ulokowania placówki zrzutowej oraz dokonania zrzutu, w tym sygnały i ich ustawienia. Po odbiorze zrzutu obsługa placówki miała odnaleźć skoczków i kontenery oraz zatrzeć ślady zrzutu. W pierwszej kolejności należało zakopać spadochrony i kombinezony skoczków, a potem rozebrać i ukryć kontenery. Następnie skoczkowie powinni oddać przywieziona pocztę i zostać odprowadzeni na kwatery. Poczta winna być ukryta i przekazana dopiero po sprawdzeniu, że zrzut nie został przez Niemców zauważony. Po zatarciu śladów i ukryciu zrzutu komendant placówki powinien przesłać meldunek, podając godzinę i miejsce zrzutu, liczbę zrzuconych skoczków i kontenerów oraz ich stan ${ }^{9}$. W pierwszym okresie, nazwanym doświadczalnym, zakończonym w kwietniu 1942 r., wykonano z Anglii osiem zrzutów lotniczych do Polski, w których trakcie przesłano zarówno ludzi tzw. cichociemnych, jak i pieniądze oraz wyposażenie wojskowe $^{10}$. O przygotowaniu do wylotu zawiadamiano placówkę zrzutową poprzez puszczenie w wyznaczonym terminie w radiu londyńskim określonej melodii.

Jednocześnie w Komendzie Głównej (KG) ZWZ w kraju (w Szefostwie Lotnictwa Oddziału V Dowodzenia i Łacczności) utworzono specjalną komórkę, nazwaną Wydziałem Odbioru Zrzutów V-S (kryptonim „Syrena”, „Import”, M II „Grad”). Działała ona co najmniej od 16 IV 1940 r., a jej szefem był kpt. Stanisław Wołkowiński „Lubicz”, zaś od połowy 1942 r. - płk dypl. Marian Dorotycz-Malewicz „Roch”, „Strzemię”. Wiosną 1942 r. komórkę odbioru zrzutów przeniesiono z Szefostwa Lotnictwa do pionu operacyjnego KG ZWZ i jako odrębny wydział zostawiono w Oddziale $\mathrm{V}^{11}$.

7 Załącznik nr 2 „Łączność przez skoczków spadochronowych” do instrukcji nr 6 dla ob. Rakonia z 3 XI 1940 r. L.dz. 875/A/tjn. 40, w: Armia Krajowa..., t. I, cz. 2, s. 590.

8 Miejsca miały być wskazywane w oparciu o mapę Polski w skali 1 : 300 000. Zob. Depesza 875/A/tjn 40, zał. nr 2 „Łączność z wami przez skoczków spadochronowych”, w: Armia Krajowa..., t. I, cz. 2, s. 519.

${ }_{9}$ Instrukcja nr 8, L.dz. 3330/41 Centrali do gen. S. Roweckiego, w: J. Tucholski, op. cit., s. 464-471. Instrukcję dostarczył kurier kpt. lot. Stanisław Niemir Bidziński ps. Karol Ziege, który skoczył na spadochronie w nocy z 7 na 8 XI $1941 \mathrm{r}$.

10 J. Tucholski, op. cit., s. 129-138.

${ }^{11}$ M. Ney-Krwawicz, Komenda Gtówna Armii Krajowej 1939-1945, Warszawa 1990, s. 173. 
Od listopada 1941 r. na terenie okupowanego kraju, w ramach Armii Krajowej (AK), działały również Wojskowe Sądy Specjalne (WSS), których zadanie stanowiło ściganie przestępstw popełnianych, na szkodę Sił Zbrojnych w Kraju, zarówno przez członków AK, jak i osoby niebędące członkami armii podziemnej ${ }^{12}$.

Naczelny Wódz - czytamy w rozkazie nr 51 gen. Roweckiego - powołał Zwiąek Walki Zbrojnej jako część sił zbrojnych RP. Ostatnio potwierdził to Naczelny Wódz rozkazem Nr 2926 z 3.IX.1941 r. W związku z tym osoby należące do ZWZ oraz organizacji i oddziałów wojskowych podporządkowanych ZWZ uważać należy za żołnierzy w czynnej służbie wojskowej, w składzie konspiracyjnej armii w Kraju znajdujacych się w obliczu nieprzyjaciela. W tym charakterze osoby wyżej wymienione podlegaja w okresie konspiracji jurysdykcji Wojskowych Sądów Specjalnych ${ }^{13}$.

Podstawą ich działania był statut WSS, który zawierał przepisy proceduralne regulujące zasady prowadzenia postępowania karnego, zarówno w fazie postępowania przygotowawczego (dochodzenia), jak i rozprawy przed sądem ${ }^{14}$. W zakresie typów przestępstw podlegających orzecznictwu sądów opierano się, zgodnie $\mathrm{z}$ art. 1 statutu WSS, na „wszystkich obowiązujących przepisach karnych", a więc zarówno na przepisach materialnych z maja 1940 r..$^{15}$, jak i przepisach sprzed II wojny światowej, tj. Kodeksie karnym z 1932 r. ${ }^{16}$, Rozporządzeniu Prezydenta Rzeczypospolitej z dnia 24 października 1937 r. o niektórych przestępstwach przeciwko bezpieczeństwu Państwa ${ }^{17}$ i Kodeksie

12 Artykuły 1 i 2 statutu WSS wskazywały, że właściwości sądów podlegały wszystkie sprawy dotyczące przestępstw przewidzianych w obowiązujących przepisach karnych popełnionych lub usiłowanych przez osoby wojskowe oraz wszystkie sprawy o przestępstwa godzace bezpośrednio w bezpieczeństwo Sił Zbrojnych w Kraju. Por. Armia Krajowa w dokumentach 1939-1945, t. II: Czerwiec 1941 - kwiecień 1943, Wrocław-Warszawa-Kraków 1991, s. 151.

${ }^{13}$ Archiwum Akt Nowych (dalej: AAN), Armia Krajowa (dalej: AK), 203/I-16, Rozkaz nr 51 gen. S. Roweckiego, z 30 X 1941 r., k. 259.

14 Statut WSS stanowił załącznik nr 1 do meldunku gen. S. Roweckiego „Kaliny” z 26 XI 1941 r. do Naczelnego Wodza. Armia Krajowa..., t. II, s. 149-153.

15 Przepisy materialne były zawarte w kodeksie Sądów Kapturowych (SK) ZWZ z 7 V 1940 r. przesłanym przez Komendanta Głównego ZWZ gen. K. Sosnkowskiego „Józefa Godziembę” do Polski (nr L.dz. 2955/Og.Tjn.40, w: Armia Krajowa..., t. I, cz. 1, s. 413). Późniejszy statut WSS, stanowiący nowelizację kodeksu SK, zawierał jedynie przepisy proceduralne, nie definiując typów przestępstw. Przepisy materialne kodeksu SK regulowały jedynie zbrodnie w postaci: zdrady, szpiegostwa, prowokacji, denuncjacji oraz nieludzkiego prześladowania i krzywdzenia ludności polskiej. Z uwagi na fakt, że zarówno te przepisy, jak i przepisy późniejszego statutu WSS z listopada 1941 r. nie zawierały innych rodzajów przestępstw, orzekano w oparciu o przedwojenne akty prawne definiujace również inne typy przestępstw, $\mathrm{np}$. jak w niniejszym przypadku przestępstwo niedopełnienia obowiązków urzędniczych wywołujące znaczną szkodę.

${ }^{16}$ Rozporządzenie Prezydenta Rzeczpospolitej z 11 VII 1932 r. Kodeks karny, Dz.U. RP 1932, nr 60, poz. 571.

17 Rozporządzenie Prezydenta Rzeczpospolitej Polskiej z 24 X 1934 r. o niektórych przestępstwach przeciwko bezpieczeństwu Państwa, Dz.U. RP 1934, nr 94, poz. 850. 
karnym wojskowym z 1932 r. ${ }^{18}$ Sprawy karne odnoszace się do przestępstw popełnionych w związku ze zrzutami lotniczymi do kraju, z uwagi na to, że wchodziły w zakres łączności lotniczej i podlegały właściwości Oddziału V KG AK, były rozpatrywane przez WSS przy KG AK ${ }^{19}$. Nadto w komórce odbioru zrzutów Oddziału V KG ZWZ-AK istniała funkcja prokuratora, którą sprawował pchor./ppor. Wincenty Orliński „Broniwój”. Jego zadaniem było wykrywanie sprawców kradzieży mienia państwowego pochodzacego ze zrzutów oraz zabezpieczenie dowodów dla WSS ${ }^{20}$. Wydaje się, że mianowanie „Broniwoja” na to stanowisko nastapiło nie wcześniej niż w kwietniu lub maju 1942 r. W sprawie bowiem kradzieży pieniędzy ze zrzutu cichociemnych na placówkę „Pole” dochodzenie od 15 do 30 III 1942 r. prowadził Janusz Zbrowski „Janusz”21. Z notatki sporządzonej przez „Broniwoja” wynika, że $14 \mathrm{~V} 1942$ r. otrzymał rozkaz mianujacy go na stanowisko prokuratora wojskowego z przydziałem służbowym do „Ewakuacji”22.

W tym czasie przewodniczącymi WSS przy KG AK byli płk Konrad Zieliński „Karola”23 i płk Witold Szulborski „Mora”24. Stanowisko prokuratora

18 Rozporządzenie Prezydenta Rzeczpospolitej Polskiej z 21 X 1932 r. Kodeks karny wojskowy, Dz.U. RP 1932, nr 91, poz. 765.

19 B. Szyprowski, Sprawy sqdowe zwiazane z mieniem zrzucanym dla Sit Zbrojnych w Kraju droga lotnicza, „Zgrupowanie Radosław” 2011, nr 5, s. 76.

${ }^{20}$ M. Ney-Krwawicz, op. cit., s. 174.

${ }^{21}$ Zrzut nastapił w nocy z 3 na 4 III 1942 r., pieniądze zaś zostały skradzione 4 III $1942 \mathrm{r}$. B. Szyprowski, Kradziė̇ pieniędzy cichociemnych z placówki „Pole” pod Wyszkowem. Wyrok Wojskowego Sadu Specjalnego na Wtadystawa Wysockiego, „Rocznik Wołomiński” 2011, t. VII, s. $215-224$.

22 AAN, AK, 203/IX-9, Notatka urzędowa W. Orlińskiego „Broniwoja” z 14 V 1942 r., k. 29; B. Szyprowski, Sprawa kradzieży pieniędzy cichociemnych z placówki „Trawa” $i$ rozwiazanie jej przez podziemny wymiar sprawiedliwości, „Przegląd Historyczno-Wojskowy” 2015, nr 1, s. 159-160.

${ }^{23}$ Pułkownik Konrad Zieliński „Karola” był od 1919 r. sędzią w sądach wojskowych, a następnie od lipca 1927 r. pełnił funkcję prokuratora w Wojskowym Sądzie Okręgowym w Lublinie, Wojskowym Sądzie Okręgowym w Warszawie i Wojskowym Sądzie Najwyższym. Od 1932 r. piastował stanowisko sędziego w sądach wojskowych. Od lutego $1941 \mathrm{r}$. do stycznia 1945 r. był szefem Służby Sprawiedliwości AK oraz przewodniczył WSS przy KG AK. A.K. Kunert, Stownik biograficzny konspiracji warszawskiej 1939-1944, t. I, Warszawa 1987, s. 166; L. Kania, Stużba Sprawiedliwości w Wojsku Polskim 1795-1945. Organizacja, prawo, ludzie, Siedlce 2015, s. 406; Instytut Pamięci Narodowej, BU 1068/89, Protokół przesłuchania podejrzanego K. Zielińskiego z 8 VII 1948 r., k. 35-42; ibidem, Protokół przesłuchania podejrzanego K. Zielińskiego z 13 VIII 1951 r., k. 128; ibidem, Protokół rozprawy sądowej K. Zielińskiego z 30 V 1952 r., k. 204; B. Szyprowski, Archiwum Wojskowego Sadu Specjalnego przy Komendzie Głównej Armii Krajowej jako „środek walki”. Sprawa karna ptk. Konrada Zielińskiego, „Zeszyty Historyczne WiN-u” 2015, nr 42, s. 176-177.

${ }^{24}$ Pułkownik Witold Szulborski „Mora”, przedwojenny adwokat, a także sędzia i prokurator wojskowy. Od marca 1941 r. zastępca Szefa Służby Sprawiedliwości ZWZ-AK płk. K. Zielińskiego „Karoli”. Przewodniczący WSS przy KG AK. A.K. Kunert, op. cit., t. I, s. 150-151; L. Kania, Stużba Sprawiedliwości..., s. 406-407. 
tego sądu piastował kpt. Lucjan Milewski „Baczyński”25, zaś w niektórych przypadkach akty oskarżenia sporządzał również „Karola”.

Czas wojny i okupacji, funkcjonowanie Sił Zbrojnych w Kraju w warunkach konspiracji i utajnienia, a co za tym idzie, brak szczególnego nadzoru nad zachowaniem żołnierzy, sprzyjały niestety ludziom o niskich instynktach, którzy podejmowali działania mające na celu kradzież lub przywłaszczenie sprzętu, a przede wszystkim pieniędzy. Sprawy takie były jednak traktowane priorytetowo i w każdym wypadku stwierdzenia niedoboru pieniędzy i broni przeprowadzano drobiazgowe dochodzenie majace na celu ustalenie szczegółów odbioru zrzutu oraz powodów ich braku. Kwestię tę uznamy za tym bardziej ważna, jeśli uzmysłowimy sobie, że pieniądze transportowane przy jednym zrzucie przez cichociemnych opiewały na bardzo duże sumy, częstokroć dochodzące lub przekraczające 500 tys. dolarów. Cichociemni zabierali ze soba pieniądze ukryte w tzw. gwoździach oraz parcianych pasach. „Gwóźdź” była to metalowa, zamknięta puszka, do której przylutowywano drut długości ok. $3 \mathrm{~m}$. W razie niebezpieczeństwa puszkę zakopywano, a drut wbijano w najbliższe drzewo, aby oznaczyć miejsce jej zakopania. W jednej puszce mogło być ukryte od 7500 do 10 tys. dolarów papierowych. Nadto skoczkowie zabierali ze soba pasy z waluta papierowa lub w monecie. Pasy te miały szelki, aby łatwiej je było nosić pod ubraniem. Ilość waluty w pasach była różna i zależna od ówczesnego zapotrzebowania i możliwości Oddziału VI Sztabu Naczelnego Wodza zajmującego się przerzutami lotniczymi do kraju. Zarówno pasy, jak i „gwoździe” numerowano. Informację o liczbie, zrzucanych z każdą ekipa cichociemnych, pasów oraz „gwoździ”, a także ich numery i zawartość przekazywano drogą radiową do kraju. W ten sposób łatwo było ustalić ewentualne braki w dostarczonych po zrzucie walorach pieniężnych. Cichociemni najczęściej przywozili ze sobą dolary i reichsmarki (RM), ale zdarzały się również pesety, ruble i franki. Po przybyciu do kraju cichociemni, na placówce odbiorczej, mieli obowiązek oddać pieniądze delegatowi KG AK, którym był żołnierz AK z komórki odbioru zrzutów. W razie jego braku pieniądze przekazywano komendantowi placówki odbiorczej. W przypadku zrzucenia zasobników ze sprzętem ich zebranie i transport zapewniała obsada placówki odbiorczej. Delegat natomiast gwarantował cichociemnym doprowadzenie do punktów kontaktowych i umożliwienie dojazdu do Warszawy, tam bowiem czekał ich okres aklimatyzacji $\mathrm{w}$ okupowanym kraju, poprzedzający przydziały służbowe w odpowiednich komórkach AK.

${ }^{25}$ Kapitan Lucjan Milewski „Baczyński” był od 1935 r. sędzia, a następnie prokuratorem wojskowych organów sprawiedliwości; od lutego 1941 r. zastępcą szefa Służby Sprawiedliwości AK oraz od jesieni 1941 r. do sierpnia 1944 r. prokuratorem WSS przy KG AK. A.K. Kunert, op. cit., t. II, s. 130-131; L. Kania, Stownik biograficzny oficerów-audytorów Stużby Sprawiedliwości Wojska Polskiego 1914-1945, cz. 1, „Wojskowy Przegląd Prawniczy" 2003, nr 4, s. 151-152. 
Latem 1941 r. Komenda Obwodu Końskie ZWZ utworzyła specjalną grupę, w skład której weszli: dowódca Stanisław Białecki „Scevola”, pchor. art. Bojomir Tworzyański „Ostoja”, Andrzej Zdziennicki „Paszko Złodziej”, pchor. lotn. Zygmunt Wyrwicz „Cumulus” i pchor. sap. Tadeusz Szatkowski „Grom”. Jej celami były wyszukiwanie miejsc na zrzutowiska oraz ochrona komendanta obwodu ${ }^{26}$. Jak wskazywał Stanisław Białecki „Scevola”, plan lądowisk i miejsce zrzutu dla obwodu koneckiego ZWZ opracowane zostały przez grupę w składzie „Ostoja”, „Cumulus” i „Scevola”. Pierwszy zrzut z Anglii nastapił w 1942 r. Zawiadomiono ich, że w dniu, kiedy radio londyńskie nada piosenkę Czerwony pas, nastapi zrzut spadochronowy, zawierający broń w kontenerach i pięciu skoczków, na dużą polanę w lesie koło Starej Kuźnicy. W stan pogotowia postawiono grupę dowodzoną przez „Cumulusa” oraz drużynę AK z Niekłania, która miała dostarczyć podwody do przewiezienia zrzutu i ubezpieczyć miejsce zrzutu. Na umówioną melodię czekali prawie dwa tygodnie. Po jej nadaniu udali się na miejsce zrzutu ${ }^{27}$. Bogumił Kacperski „Malina” wspominał, że któregoś wieczora, wiosna 1942 r., przyszedł do niego „Cumulus” i przekazał mu informację, żeby zebrał podległa mu drużynę z Końskich i czekał na dalsze rozkazy do godz. 23.15. „Malina” zarządził zbiórkę drużyny, jednak tego dnia czekali daremnie. Alarm odwołano. Następnego dnia dowiedział się od por. Bolesława Czerwińskiego „Kaliny”, „Wira”, że zarządził on pogotowie w związku z mającym nastapić zrzutem skoczków i zaopatrzenia z Anglii. Znakiem do przygotowania ustalonych wcześniej zrzutowisk winno być nadanie umówionych melodii przez radio. Melodia ta miała zostać podana najpierw o godz. 17.00-17.15, a następnie powtórzona o godz. 23.00. Brak ponowienia melodii oznaczał, że samolot nie wystartował lub zawrócił z drogi ${ }^{28}$. 30 III 1942 r. o godz. 19.05 z lotniska Tempsford wystartował Halifax L-9613 „V” pod dowództwem pilota F/O Ryszarda Zygmuntowicza ${ }^{29}$, który wykonując operację „Belt”, zabrał VII ekipę cichociemnych na placówkę odbioru zrzutu o kryptonimie „Kopyto”, położoną $8 \mathrm{~km}$ na północny wschód od Końskich ${ }^{30}$. Po odebraniu melodii o godz. 23.00 drużyna „Maliny” wyruszyła kilkoma grupami na miejsce zrzutu, tj. polanę za miejscowością Witków. Drużyna miała dojść do skraju lasu przy drodze prowadzącej do Starej Kuźnicy i Piasków. Drużyna „Maliny” nie była

${ }^{26}$ B. Kacperski, J.Z. Wroniszewski, Końskie i powiat konecki 1939-1945, cz. 3: Konspiracja konecka 1939-1945, Końskie 2005, s. 29.

${ }^{27}$ Relacja Stanisława Białeckiego „Scevoli” z 6 III 1984 r., w: B. Kacperski, J.Z. Wroniszewski, op. cit., s. 102-103.

${ }^{28}$ B. Kacperski, Pierwszy zrzut, w: B. Kacperski, J.Z. Wroniszewski, op. cit., s. 119.

${ }^{29}$ Kajetan Bieniecki wskazywał, że w załodze Halifaxa było 8 osób, w tym dowódca pilot F/O Ryszard Zygmuntowicz, pilot F/O Krzysztof Dobromirski, nawigator F/O Antoni Voellnagel, radiooperator sierż. Leon Wilmański, mechanik sierż. Czesław Mądracki, despatcher sierż. Bronisław Karbowski, strzelec pokładowy sierż. Mieczysław Wojciechowski, strzelec pokładowy F/S Wacław Żuk. K. Bieniecki, Lotnicze wsparcie Armii Krajowej, Kraków 1994, s. 353.

${ }^{30}$ J. Tucholski, op. cit., s. 167. 
uzbrojona, bowiem stanowiła grupe przyjmujaca zrzut. Ubezpieczenie zrzutu miała wystawić placówka AK z Niekłania ${ }^{31}$. Żołnierze placówki odbiorczej zajęli stanowiska na polanie. Wyposażeni w latarki zostali ustawieni w kształcie strzałki wskazującej kierunek wiatru. Około godz. 1.00 w nocy usłyszeli warkot silników samolotu, który zaczęto obserwować. Po zauważeniu na jego skrzydłach umówionych świateł zapalono latarki. Samolot jednak przeleciał nad placówka, nie dokonując zrzutu. Obsada placówki bezskutecznie czekała do rana. W momencie kiedy częściowo zwinięto placówkę, a część żołnierzy udała się do domów lub do pracy, uzyskano informację, że samolot jednak dokonał zrzutu. „Cumulus” polecił, będącym w pracy „Malinie” i Kazimierzowi Chojniarzowi „Walczowi”, poszukiwać miejsca dokonania zrzutu. Pomimo podjętych przez nich czynności od godz. 9.00 do 14.00 nic nie ustalono. Dopiero ok. godz. 15.00 „Malina” został powiadomiony o miejscu dokonania zrzutu ${ }^{32}$. Nastapił on ok. godz. 01.10 w nocy. Samolot pomyłkowo zrzucił cichociemnych, 4 zasobniki i 2 bagażniki w odległości $6 \mathrm{~km}$ od placówki odbiorczej, w pobliżu obozu jeńców sowieckich w Baryczy. Zrzut wykonano na skraju lasu za Młynkiem Nieświńskim, ok. 800 m od drogi do Nieświnia, a nie, jak oczekiwano, na placówce koło Witkowa. Dwóch skoczków o godz. 10.00 zgłosiło się na punkt kontaktowy ${ }^{33}$. Do kraju skoczyli: dowódca ekipy - rtm. kaw. Jerzy Sokołowski „Mira”, por. rez. lot. Jan Jokiel „Ligota”, por. rez. art. Stefan Majewicz „Hruby”, por. piech. Piotr Motylewicz „Krzemień”, mjr dypl. kaw. Tadeusz Sokołowski „Trop” oraz kurier polityczny ppor. Jerzy Mara-Mayer „Filip”, „Vis”34.

19 V 1942 r. członek „Ewakuacji” z Warszawy „Kostek” (NN), przy udziale „Broniwoja” i „Romana”, przesłuchał komendanta placówki „Kopyto”, Mariana

${ }^{31}$ B. Kacperski, Pierwszy zrzut..., s. 119. Jak wspominał Ludwik Nowiński „Sęp”, w obstawie zrzutu byli m.in. Jan Stanisławski „Igo” i L. Nowiński „Sęp”. Relacja L. Nowińskiego z 20 VII 1986 r., w: B. Kacperski, J.Z. Wroniszewski, op. cit., s. 82.

${ }^{32}$ Relacja Stanisława Białeckiego..., s. 103. Jak wspominał Bogumił Kacperski „Malina”, w tym czasie część jego drużyny pracowała zarobkowo i dlatego żołnierze wrócili do miasta. „Malina”, „Cumulus” i „Walcz” pracowali w Zakładach Przemysłowych „Neptun”. B. Kacperski, Pierwszy zrzut..., s. 120.

33 J. Tucholski, op. cit., s. 137. Jak wskazywał „Malina”, jeden ze skoczków zgłosił się na skrzynkę kontaktową do sklepu elektrycznego Chodaczyńskich w Końskich i podał hasło: „Czy ma pan do sprzedania granatowy garnitur”. Skoczków mieli ewakuować, do lokalu w Końskich, Kujdowicz i Marian Czerwiński „Socha” (B. Kacperski, Pierwszy zrzut..., s. 120, 122). Stanisław Białecki podawał, że skoczkowie zgłosili się na podany im w Anglii punkt kontaktowy w księgarni Jędryków (Relacja Stanisława Białeckiego..., s. 103). Jak wskazywał Cezary Chlebowski, na punkt kontaktowy w Końskich, mieszczący się w sklepie Chodaczyńskich, poszedł rtm. T. Sokołowski „Trop”. W punkcie obowiązywało hasło: „Czy ma pan do sprzedania granatowy garnitur” i odzew: „Mam, ale marynarka jest przyciasna” (C. Chlebowski, Cztery z tysiaca, Warszawa 1981, s. 120-121).

${ }^{34}$ J. Tucholski, op. cit., s. 167.

${ }^{35} \mathrm{~W}$ podpisie protokołu występuje pod pseudonimem Jankowski. AAN, AK, 203/IX-6, k. 57a, Protokół przesłuchania Mariana Słomińskiego „Babinicza” i Bolesława Czerwińskiego „Wira” z 19 V 1943 r. 
Słomińskiego „Babinicza” ${ }^{6}$ i jego zastępcę Bolesława Czerwińskiego „Wira” ${ }^{37}$. Wskazali oni, że 31 III 1942 r. o godz. 2.05 zrzucono 6 skoczków ze sprzętem; w sumie 10 spadochronów. Zrzut przeprowadzono w odległości $6 \mathrm{~km}$ od placówki, stąd jej obsada nic o tym nie widziała. Na placówce odbiorczej czuwało 18 członków ZWZ. Przygotowano również dwa wozy konne do ewakuacji sprzętu. Około godz. $2.00 \mathrm{w}$ nocy obsada placówki widziała lecący samolot. Wówczas zapaliła latarki w kształcie strzały, na co samolot odpowiedział światłami, wskazując, że zauważył placówkę. Samolot jednak nie nadleciał nad samą placówkę, skręcając przed nią ok. 0,5 km w lewo. Wkrótce placówka straciła go z oczu. Słyszano jedynie, że gdzieś dalej zatoczył koło. Stąd sądzono, że był to samolot niemiecki. Żołnierze ZWZ czuwali jednak do godz. 5.00 rano. Następnie rozeszli się do domów, sądząc, że żaden zrzut się nie odbył. Około godz. 10.00 do lokalu kontaktowego dla cichociemnych w Końskich zgłosił się jeden ze skoczków, a następnie po nim drugi skoczek. Wówczas „Wir” udał się z jednym z nich na miejsce zrzutu. Po drodze dowiedział się, że cichociemni przywieźli: 5 pasów z dolarami w złocie, 5 pasów z dolarami papierowymi, 4 kontenery, 2 bagażniki, pas kuriera politycznego oraz rzeczy i broń osobista skoczków. Po drodze cichociemny pokazał „Wirowi”, gdzie leżały 4 kontenery. Trzy z nich znajdowały się na poligonie, skąd doskonale widać było obóz jeńców sowieckich. Czwarty kontener leżał na skraju lasu w odległości ok. $80 \mathrm{~m}$ od pozostałych. Wszystkie zasobniki były przykryte płótnem spadochronowym, z dala imitujacymm kępki trawy. Jednak z odległości $50 \mathrm{~m}$ były doskonale rozpoznawalne. Następnie „Wir” ze skoczkiem przeszli koło miejsca, gdzie cichociemni zakopali 2 bagażniki, kombinezony skoczków oraz resztę spadochronów. Miejsce to znajdowało się w odległości $600 \mathrm{~m}$ od kontenerów i było doskonale zamaskowane. Około 1,5 km od tego miejsca ukryli się, na poligonie w gęstych krzakach, pozostali czterej cichociemni. „Wir” dotarł do nich ok. godz. 12.30. Skoczkowie posiadali przy sobie 5 pasów z dolarami w złocie, 5 pasów z dolarami papierowymi, pocztę, pas „polityczny”, rzeczy prywatne i broń osobista. W tym czasie na miejsce dotarło dwóch członków placówki AK ściagniętych z miasta. Sporządzono protokół opisujacy liczbę pasów oraz pozostały sprzęt. Z uwagi na możliwe zauważenie zrzutu przez Niemców oraz fakt, że zasobniki leżały na otwartej przestrzeni, ustalono, że „Wir” odprowadzi cichociemnych do miasta, zabierając jedynie pocztę i ich rzeczy osobiste. Na miejsce zrzutu zostali wysłani dwaj żołnierze AK celem zakopania pieniędzy i broni. O zmroku mieli tam dotrzeć pozostali żołnierze AK, aby zakopać zasobniki. Cichociemni i „Wir”,

${ }^{36}$ Porucznik Marian Słomiński „Babinicz” od lata 1940 r. był szefem referatu III Komendy Obwodu Koneckiego ZWZ-AK. J.Z. Wroniszewski, Dzieje obwodu od 1.XI.1939 do 20.VIII.1943 r., w: B. Kacperski, J.Z. Wroniszewski, op. cit., s. 13, 19; Relacja L. Nowińskiego..., s. 81.

${ }^{37}$ Pseudonimem Wir posługiwał się Bolesław Czerwiński. Por. B. Czerwiński „Kalina”, „Wir”, Wspomnienia z okresu okupacji mjr. Bolesława Czerwińskiego, w: B. Kacperski, J.Z. Wroniszewski, op. cit., s. 63. 
idąc po dwóch, w pewnych odstępach od siebie, opuścili miejsce zrzutu. Kwatera dla cichociemnych miał być początkowo dom Czerwińskich przy ul. Dworcowej w Końskich. Potem podzielono ich na dwie grupy i jedna umieszczono na plebanii, a druga w letniej altance niedaleko koneckiego gestapo $^{38}$. Żołnierze AK, którzy pozostali na miejscu, zakopali pasy z pieniędzmi i broń: w jednym miejscu - pasy z pieniędzmi (np. dolarami) i pas „polityczny”, zaś w innym - pasy z dolarami papierowymi i broń osobista. Około godz. 19.00 „Wir” wysłał na miejsce zrzutu siedmiu żołnierzy AK. Wieczorem, po powrocie na miejsce zrzutu, ustalono, że ok. godz. 21.00 Niemcy wystawili koło kontenerów wartę złożoną z dwóch żandarmów i policjanta „granatowego”. Z tego powodu ich ukrycie okazało się niemożliwe. Udało się jedynie wykopać pasy z dolarami złotymi i pas „polityczny”. Nadto, po podczołganiu się, zdołano częściowo opróżnić jeden kontener. Zabrano 3 pistolety maszynowe, 4 colty, 8 granatów i amunicję ${ }^{39}$. Nie zdołano wykopać pasów $\mathrm{z}$ dolarami papierowymi, bo w pobliżu ich zakopania stała warta niemiecka. Z uwagi na nadciagające oddziały niemieckie akowcy wycofali się ${ }^{40}$. „Malina” zorganizował grupę żołnierzy, liczacca ok. 10 osób, celem ewakuacji sprzętu. W skład grupy wchodzili m.in. Tadeusz Drzewiecki „Soból”, Jerzy Drzewiecki „Czyżyk”, Józef Wilk „Czajka” i Kazimierz Chojniarz „Walcz”. Udano się do domu Tworzyańskich na Koczwarę, skąd ok. godz. 22.00 żołnierze AK podażyli w kierunku miejsca zrzutu. Po drodze zauważyli żołnierzy niemieckich, którzy, jak sądził „Malina”, przeszukiwali teren po uzyskaniu informacji o zrzucie. Żołnierze AK zaczęli się wycofywać z zagrożonego miejsca, a po chwili spotkali „Cumulusa”. Ten poinformował ich o ewakuacji skoczków, zakopaniu części sprzętu i przeszukaniu, prawdopodobnie przez okolicznych gospodarzy, części kontenerów zrzutowych. Jednocześnie „Cumulus” wręczył im colty, zaś „Malinie” - pas z dokumentami i pieniędzmi. Zajęto się też ewakuacją, do domu Tworzyańskich, sprzętu przyniesionego przez „Cumulusa”" ${ }^{41}$ Wojsko niemieckie patrolowało i przeszukiwało okolicę przez tydzień. Po tym okresie Niemcy opuścili teren zrzutu. Gdy Niemcy ściagnęli warty,

${ }^{38}$ C. Chlebowski, op. cit., s. 124.

${ }^{39} \mathrm{~W}$ książce Cezarego Chlebowskiego zostało wskazane błędnie, że żołnierze AK zabezpieczyli wszystkie zrzucone zasobniki (ibidem, s. 118-120, 125). Udało się uratować jedynie zawartość 2 bagażników (radiostacje), większość pieniędzy i część broni z 1 kontenera. Pozostałe 3 kontenery zabrali Niemcy. Z powojennej relacji S. Białeckiego wynikało, że na miejscu zrzutu skoczkowie zostawili 2 kontenery z materiałami minerskimi, pasy osobiste z pieniędzmi i zakopaną broń osobistą. Wieczorem żołnierze placówki udali się w to miejsce. Zabrali zawartość kontenerów na Koczwarę, a stamtąd kilka dni później samochodem ewakuowano je dalej. Na miejscu zrzutu nie znaleziono zakopanych pasów z pieniędzmi i broni skoczków. Relacja Stanisława Białeckiego..., s. 103.

${ }^{40}$ AAN, AK, 203/IX-6, Protokół przesłuchania Mariana Słomińskiego „Babinicza” i Bolesława Czerwińskiego „Wira” z 19 V 1943 r., k. 56-57a.

${ }^{41}$ B. Kacperski, Pierwszy zrzut..., s. 121-122. 
udano się po resztę zakopanych pasów i 2 bagażniki. Wówczas stwierdzono, że zostały one wykopane. Podejrzenie padło na okolicznych mieszkańców mogacych podpatrzyć, jak je zakopywano, bowiem miejsce to znajdowało się w pobliżu wioski. „Babinicz” zarządził obserwację ww. chłopów. Jeden z żołnierzy AK poinformował go, że ubogi chłop z wioski chciał pożyczyć 400 zł, obiecując oddać pięciokrotnie więcej po wojnie. Kierując się tym śladem, wysłano do niego 8 żołnierzy, którzy poinformowali go, że dokonał kradzieży pieniędzy wojskowych. Jednocześnie zagrożono mu śmiercią ${ }^{42}$. W odpowiedzi mężczyzna przyznał się do zabrania pieniędzy i wskazał miejsce ich ukrycia. Część pieniędzy została zakopana, w szklanych słojach, w ogrodzie i posadzono w tym miejscu drzewko, 40 dolarów schowano w butelce i zakopano, a część zamurowano za piecem w domu. Pieniądze przeniesiono do miasta i komisyjnie przeliczono. Były to dolary papierowe w ilości 220 950. Odzyskano również łącznie 7 pistoletów. 5 pistoletów uzyskano od razu, zaś po kilku dniach dwa następne. Kilka dni później odnaleziono jeszcze 50 dolarów. Łącznie odzyskano 221 tys. dolarów. Nadto „Babinicz” dowiedział się, że inny chłop znalazł sprzęt zrzucony w bagażnikach. „Babinicz” ustalił, że mężczyzna odkrył sprzęt, który leżał przy drodze koło lasu. Odzyskano 3 aparaty nadawczo-odbiorcze, 3 rolki bibuły japońskiej, 2 aparaty radiowe, 1 pudełko filmów, 5 kwarców, 1 paczkę żarówek i 2 generatory. Sprzęt ten został ewakuowany przez „Kostka” do Warszawy. Złote i papierowe dolary zabezpieczył i ukrył „Babinicz”. Zakopanych spadochronów, kombinezonów oraz płacht gumowych nie odnaleziono ${ }^{43}$. Pieniądze ze zrzutu przewiozły do Warszawy pociagiem Maria Nowak „Wacka” i Krystyna Gołębiowska ${ }^{44}$.

Na podstawie depeszy z Londynu ustalono, że cichociemni zabrali ze sobą 5 pasów z dolarami w łącznej kwocie 249 tys. dolarów papierowych ${ }^{45}$. Nadal brakowało więc 28 tys. dolarów papierowych. Była to niebagatelna

\footnotetext{
${ }^{42} \mathrm{~W}$ powojennej relacji S. Białecki wskazywał, że „Scevola” zarządził obserwację rynku walutowego przez podległych sobie żołnierzy AK. Po upływie miesiąca Jerzy Jabłoński „Jerz” zameldował, że jeden z mieszkańców Młynka Nieświńskiego chciał sprzedać banknot o nominale 20 dolarów. Do jego miejsca zamieszkania udało się, po pewnym czasie, w porze nocnej 5 żołnierzy AK, którym przyznał się do zaobserwowania zrzutu i odkopania schowanych przedmiotów. Zwrócił zabrane pieniądze oraz broń skoczków. W jednej z paczek brakowało 20 dolarów, które zdążył sprzedać. Po powrocie na kwaterę sporządzono protokół z odnalezienia przedmiotów, który wraz z uzyskanymi pieniędzmi przesłano do Warszawy. Broń osobistą skoczków, za ich zgoda, zatrzymali żołnierze placówki AK. Relacja Stanisława Białeckiego..., s. 103.

${ }^{43}$ AAN, AK, 203/IX-6, Protokół przesłuchania Mariana Słomińskiego „Babinicza” i Bolesława Czerwińskiego „Wira” z 19 V 1943 r., k. 56-57a. „Scevola” - pchor. Stanisław Białecki; „Ostoja” - ppor. Bojomir Tworzyański. Por. J.Z. Wroniszewski, op. cit., s. 13, 19; Relacja L. Nowińskiego..., s. 81.

${ }^{44}$ M. Nowak-Dobrzańska „Wacka”, Przewóz zrzutu, w: B. Kacperski, J.Z. Wroniszewski, op. cit., s. 123.

${ }^{45}$ AAN, AK, 203/IX-6, Odpis depeszy nr 1751 z 3/7 IV 1943 r., k. 66.
} 
suma, biorąc pod uwagę ceny dolarów obowiązujące w czasie okupacji „na czarnym rynku"46.

Przesłuchany 20 V 1942 r. „Babinicz” wskazał, że on jako komendant placówki „Kopyto” wydawał wszystkie zarządzenia związane z przygotowaniem i odbiorem zrzutu. On też dowodził placówką 30 III 1942 r. Nazajutrz polecił „Wirowi” udać się na miejsce zrzutu z jednym ze skoczków, a także wieczorem wysłał tam ludzi celem zabrania pasów z pieniędzmi, paczki Jerzego $^{47}, 2$ bagażników oraz ewentualnie 4 dużych kontenerów. O ile nie byłoby możliwe przywiezienie 4 kontenerów, miano je przetransportować w inne miejsce i zakopać. Jednak fakt przebywania Niemców na miejscu zrzutu uniemożliwił powyższe działanie. Trzy kontenery zabrali Niemcy. $\mathrm{Z}$ czwartego kontenera udało się wziąc 3 pistolety maszynowe $\mathrm{z}$ amunicja, 4 colty i 8 granatów. Zawartość 2 bagażników, poza 2 aparatami fotograficznymi marki „Leica”, została odzyskana od innego chłopa. Nie dowiedziano się o ich dalszym losie. Po uzyskaniu informacji, że pieniądze zabrał chłop o nazwisku Szczepaniak, „Babinicz” wysłał do niego drużynę szturmowa, aby je odebrać siła. Wtedy też żołnierze AK przeliczyli je. Po przyniesieniu dolarów na kwaterę dowódcy drużyny został sporządzony protokół z ich przeliczenia. Jednakże dowódca drużyny nie rozrywał poszczególnych paczek z pieniędzmi. Stąd przy późniejszym podliczaniu pieniędzy przez „Babinicza” ogólna suma nie zgadzała się, bowiem była większa niż powinna. Zdaniem „Babinicza” nikt z drużyny szturmowej nie przywłaszczył części pieniędzy. Przy sporządzaniu protokołu z przeliczenia pieniędzy, oprócz „Babinicza”, było obecnych trzech członków komisji. Po przewiezieniu pieniędzy do Warszawy ponownie je policzono. Wówczas „Babinicz” uzyskał informację, że łącznie ze zrzutu brakowało 28 tys. dolarów ${ }^{48}$.

„Wir” zeznał, że jako zastępca komendanta placówki pojechał na miejsce zrzutu z jednym ze skoczków. Tam sporządził protokół opisania pieniędzy i sprzętu. Protokół ten później, po ewakuacji pieniędzy i sprzętu do Warszawy, zniszczył. Nie opisywał w nim ilościowo pieniędzy, lecz wskazał jedynie liczbę pasów: 5 pasów ze złotem, 5 pasów z dolarami papierowymi oraz 1 pas kuriera politycznego. „Wir” sprawdzał, że pasy z pieniędzmi papierowymi

${ }^{46}$ Przed wybuchem II wojny światowej za 1 dolara papierowego płacono 5 zł. W Warszawie, w czasie okupacji, na „czarnym rynku” 1 dolar papierowy miał wartość: w styczniu $1940 \mathrm{r}$. - 100 zł, w styczniu 1943 r. - 165 zł, a w lutym 1944 r. - 150 zł. W styczniu 1943 r. 1 dolar złoty kosztował 440 zł. W lutym 1943 r. kurs dolara papierowego w Warszawie spadł do 150-110 zł, zaś dolara złotego - do 435-365 zł, co było związane z wyprzedawaniem dolarów przez uciekinierów z getta warszawskiego i dużą ilością tej waluty w obiegu „czarnorynkowym”. W styczniu 1944 r. kurs przeliczeniowy 1 dolara złotego wynosił 750 zł. W. Bartoszewski, 1859 dni Warszawy, Kraków 1974, s. 103, 342-343, 345, 503.

${ }^{47}$ Prawdopodobnie chodzi o pas tzw. polityczny, przywieziony przez kuriera Delegatury Rządu Jerzego Mary-Meyera „Filipa”.

${ }^{48}$ AAN, AK, 203/IX-6, Protokół przesłuchania M. Słomińskiego „Babinicza” z 20 V 1942 r., k. 58 . 
miały wypełnione całkowicie wszystkie kieszenie, które były zaszyte. „Wir” nie potrafił wskazać, czy część tych pasów zawierała 5, a część - 6 kieszeni, bowiem ich nie liczył. Kiedy odbierał pieniądze papierowe od członka drużyny szturmowej, Tomira Tworzyańskiego „Borsuka”49, ten zapytał go, czy pieniadze nie były zapakowane w 30 paczkach. Powyższe odpowiadałoby łącznie 30 kieszeniom z 5 pasów. Z tego, co pamiętał „Wir”, „Borsuk” powiedział mu, że odbierał 27 lub 28 paczek. Pasy w lesie ukrywali Marian Czerwiński „Socha"50 i „Cumulus”.

„Cumulus” zeznał, że razem z „Sochą” pasy cichociemnych zakopywali $\mathrm{w}$ trzech różnych miejscach na polu i na skraju lasu. Wszystkie pasy z pieniędzmi papierowymi były jednakowej długości. Jak mu się wydawało, kieszenie $\mathrm{w}$ tych pasach miały także jednakową grubość. Nie liczył kieszeni w każdym pasie, ale każda kieszeń była pełna. Zakopali łącznie 5 pasów z dolarami papierowymi oraz 7 pistoletów. Następnie wraz z "Sochą" pełnił służbę przy pozostałym sprzęcie od godz. 13.30 do 22.00 . W tym czasie „Cumulus”, powodowany ciekawościa, otworzył jeden z kontenerów, leżący na skraju lasu. Z tego kontenera on i „Socha” zabrali wieczorem część broni i granatów, aby przy przenoszeniu pieniędzy mieć się czym bronić w razie ataku Niemców. Gdy pełnili służbę, po polu kręcili się chłopi, których „Cumulus” nie dopuszczał blisko sprzętu. Około godz. 21.00 na miejsce przyjechał samochód z żandarmami, którzy oglądali leżące kontenery. Po jakimś czasie odjechali, pozostawiając trzech wartowników. Wówczas czujka AK wycofała się w stronę lasu. Około godz. 21.45 na miejsce przyszło 8 członków AK celem ewakuacji sprzętu. „Cumulus” dał im broń wyjęta z kontenera. Wraz z inną osobą odkopał pasy z dolarami złotymi oraz pas kuriera politycznego. Nie ruszano pasów z dolarami papierowymi, bowiem miejsce ich zakopania znajdowało się niedaleko wartowników i było doskonale widoczne z powodu jasnej księżycowej nocy i odkrytego terenu. Nadto pasów tych nie miałby kto zabrać, bo wszyscy żołnierze byli obładowani sprzętem, który ewakuowali52.

„Socha” wskazał, że na miejsce zrzutu przybył z „Cumulusem” ok. godz. 12.00. Zastał tam „Wira” i 5 cichociemnych. „Wir” polecił jemu i „Cumulusowi”

49 Tomir Tworzyański „Borsuk” od końca grudnia 1939 r. zajmował się nasłuchem radiowym, redagowaniem tekstów i wydawaniem gazetki „Sprawy Polskie”. Następnie był szefem referatu VI Komendy Obwodu AK Końskie. Zginął w nocy z 1 na 2 XI 1942 r. w swoim domu na Koczwarze koło Końskich, podczas próby aresztowania przez Niemców. B. Kacperski, J.Z. Wroniszewski, op. cit., s. 21, 35.

50 Marian Czerwiński „Socha” (ur. w 1922 r.) - od 1941 r. był członkiem plutonu 201 ZWZ-AK dowodzonego przez B. Kacperskiego „Malinę”, który podlegał Komendantowi Miasta Końskie. W 1942 r. został szefem łączników placówki miejskiej Końskie o kryptonimie „Wierch”. Zastępcą dowódcy plutonu 201 AK był Z. Wyrwicz „Cumulus”. B. Kacperski, Pluton 201, w: B. Kacperski, J.Z. Wroniszewski, op. cit., s. 78, 208.

${ }^{51}$ AAN, AK, 203/IX-6, Protokół przesłuchania B. Czerwińskiego „Wira” z 20 V 1942 r., k. 58-59.

52 Ibidem, Protokół przesłuchania Z. Wyrwicza „Cumulusa” z 20 V 1942 r., k. 59. 
zakopać pasy z pieniędzmi i dozorować sprzęt do czasu nadejścia członków placówki AK. Po ich przyjściu mieli przewieźć sprzęt w ustalone miejsce lub w najgorszym razie zakopać leżące na polu 4 kontenery. Jeszcze podczas pobytu cichociemnych na miejscu zrzutu zaczęto zakopywać pasy z pieniędzmi w trzech oddzielnych miejscach. W jednym miejscu „Cumulus” i „Socha” zakopali pasy z dolarami złotymi, w drugim - pasy z dolarami papierowymi oraz 7 pistoletów, zaś w kolejnym - pas „polityczny”. Jak wskazywał „Socha”, pasy z dolarami papierowymi były równej długości, z pełnymi, zaszytymi kieszeniami, lecz wydawało mu się, że nie wszystkie pasy miały taką sama liczbę kieszeni. Podczas dozorowania sprzętu widział chłopów kręcących się na polu, w pobliżu kontenerów. Około godz. 19.30 „Socha” został zmieniony przez innego żołnierza i wrócił do domu. Do tego czasu na miejsce nie przybyli jeszcze Niemcy ${ }^{53}$.

„Ostoja” zeznał, że był wśród 7 osób odbierających dolary papierowe od chłopów, którzy je przywłaszczyli. Okazało się, że zabrali oni 5 pasów. Pieniędzy jednak w pasach nie przechowywali. Część dolarów była umieszczona $\mathrm{w}$ drewnianej skrzynce, reszta zaś w dwóch słojach oraz szklanej butelce. Jeden ze słoi podczas wykopywania stłukł się. Po odebraniu pieniędzy nie liczono ich na miejscu. Pieniądze te „Ostoja” i inne osoby, idąc na konspiracyjna kwaterę, nieśli na zmianę. Dolary znajdowały się w nieodpieczętowanych opakowaniach. Dopiero na kwaterze, w obecności „Borsuka”, „Iskry”, „Scevoli” i „Ostoi”, przeliczono pieniądze i sporządzono protokół. „Ostoja” nie pamiętał dokładnie, ile było pieniędzy. Po kilku dniach pieniądze odebrał kierownik placówki, który sporządził nowy protokół. Wówczas protokół spisany przez „Ostoję" został zniszczony ${ }^{54}$.

3 IV 1942 r., w obecności „Babinicza”, „Tylskiego”, „Kory” i „Borsuka”, sporządzono protokół z odebrania pieniędzy. Wskazano w nim, że po stwierdzeniu kradzieży 5 pasów zarządzono obserwację terenu i 20 IV $1942 \mathrm{r}$. ustalono, u kogo znajduja się skradzione pieniądze. W nocy z 20 na 21 IV 1942 r. odebrano pieniądze od sprawcy kradzieży. Pieniądze zostały wypakowane z pasów. Odebrano łącznie 27 paczek banknotów o różnych nominałach, a następnie dołączono do nich otrzymane 50 dolarów. Odzyskane 50 dolarów było w różnych banknotach o nominałach: 1 sztuka - 20 dolarów, 2 sztuki banknotów po 10 dolarów i 2 sztuki banknotów po 5 dolarów. Łączna suma pieniędzy wynosiła 221 tys. dolarów papierowych ${ }^{55}$.

${ }^{53}$ Ibidem, Protokół przesłuchania M. Czerwińskiego „Sochy” z 20 V 1942 r., k. 60.

${ }^{54}$ Ibidem, Protokół przesłuchania B. Tworzyańskiego „Ostoi” z 20 V 1942 r., k. 60. Podchorąży art. Bojomir Tworzyański ps. Ostoja był od końca 1939 r. w ZWZ w Końskich, a jesienia 1940 r. został członkiem ZWZ-AK w grupie do zadań specjalnych pod dowództwem Białeckiego „Scevoli”. W nocy z 1 na 2 XI 1942 r. Niemcy chcieli go aresztować, lecz „Ostoja” wraz z „Scevolą” przebili się z otoczonego domu. J.Z. Wroniszewski, op. cit., s. $13,29,35$.

${ }^{55}$ AAN, AK, 203/IX-6, Protokół odbioru pieniędzy z 31 IV 1942 r., k. 65. 
Natomiast 21 V 1942 r. „Broniwój” dokonał wizji lokalnej miejsca placówki „Kopyto” i ustalił, że zeznania członków placówki w przedmiocie „dzikiego” zrzutu, miejsc zakopania pieniędzy, zrzucenia kontenerów oraz niemożliwości ich zabezpieczenia były zgodne z rzeczywistością ${ }^{56}$.

$\mathrm{Z}$ protokołu przesłuchania trzech mężczyzn, którzy odnaleźli dolary, wynikało, że obserwowali oni zrzut, będąc we własnych zabudowaniach gospodarskich oddalonych ok. 300-400 m od tego miejsca. Gdy Niemcy zabrali kontenery i opuścili teren, mężczyźni wspólnie rozpoczęli przeszukiwanie miejsca zrzutu. W pewnym momencie jeden $\mathrm{z}$ nich odnalazł kawałek terenu świadczący o świeżo przekopywanej ziemi. Zaczęli rozkopywać to miejsce i znaleźli 5 pasów i 7 pistoletów; pasy były nienaruszone. Trzy lub cztery pasy miały po 6 kieszeni, a jeden lub dwa - po 5 kieszeni. W sumie w pasach było 28 lub 29 kieszeni. Pasy i broń zabrali do domu. Tam rozerwali jedna paczkę i stwierdzili, że zawiera pieniądze. Rozdzielili je między siebie. 16 nienaruszonych paczek z dolarami schowali do skrzyni, którą zakopali w domu pod piecem. Następne 10 paczek schowali do słoja, który zakopali w ogrodzie pod drzewem. 2 lub 3 paczki, z których jedna była rozpieczętowana i brakowało 50 dolarów, schowali do drugiego słoja, który zakopali pod progiem domu. 50 dolarów przeznaczonych na wymianę upchali w oddzielnej butelce. Mężczyźni uważali, że pieniądze pochodzą z desantu bolszewickiego. Trzy tygodnie później po odbiór pieniędzy przyszło 8 uzbrojonych ludzi. Chłopi uznali ich za bandytów i nie chcieli zdradzić posiadania pieniędzy. Dopiero gdy zostali pobici i grożono im śmiercią (powieszeniem), przyznali się i oddali prawie wszystkie schowane pieniądze - oprócz 50 dolarów, o których zapomnieli. Brakująca kwotę zwrócili kilka dni później, podkreślając, że oddali wszystkie znalezione pieniądze ${ }^{57}$.

„Broniwój” wystapił o uzyskanie odpisu radiogramu podającego ilość pieniędzy zrzuconych na placówkę. Nadto polecał sprawdzenie w Londynie, czy pasy były zamykane komisyjnie i czy sporządzono protokół z tej czynności, jak zostały zapakowane pieniądze w pięciu pasach, zwłaszcza po ile kieszeni miały poszczególne pasy oraz po ile banknotów i w jakim nominale zapakowano do każdej kieszeni. Kolejną kwestię, o którą się zwracał „Broniwój, stanowiło ustalenie, czy pasy z pieniędzmi papierowymi były tej samej długości. Chciał wyjaśnić, czy wszystkie pasy miały po 6 kieszeni czy też dwa z nich posiadały ich 5 oraz czy poszczególne kieszenie były równej grubości. W konkluzji pytał, czy niektóre zawierały więcej banknotów niż pozostałe. W tym zakresie „Broniwój” polecał przesłuchanie kasjera i członków załogi samolotu ${ }^{58}$.

${ }^{56}$ Ibidem, Protokół wizji lokalnej z 21 V 1942 r., k. 61.

${ }^{57}$ Ibidem, Protokół przesłuchania Szczepaniaków i Ferenca z 21 V 1942 r., k. 61. Jak wskazywał „Broniwój”, ze sposobu oddawania pieniędzy, stopnia zmaltretowania (fizycznego i psychicznego) oraz sposobu zeznawania tych osób fakt oddania przez nich całości znalezionych pieniędzy nie budził wątpliwości.

58 Ibidem, Pismo Z. Orlińskiego „Broniwoja” z 23 V 1942 r., k. 64. 
Z odpisu radiogramu wynikało, że ekipa cichociemnych Jerzego Sokołowskiego „Miry” zabrała 249 tys. dolarów papierowych umieszczonych w pasach: nr 2729-2730, 2735-2736 i $2738^{59}$. W toku czynności ustalono, że paczki z banknotami były wszystkie równej grubości i zawierały każda po 300 banknotów o różnych nominałach ${ }^{60}$. Na podstawie kolejnej depeszy stwierdzono, że pas nr 2729 miał 6 kieszeni i zawierał, w banknotach o nominałach 50, 20 i 10 dolarów, łącznie 34 tys. dolarów ${ }^{61}$; pas nr 2730 - 6 kieszeni i łącznie 39 tys. dolarów w banknotach o nominałach 50 i 20 dolarów ${ }^{62}$; pas nr 2735 - 6 kieszeni i łącznie 60 tys. dolarów w banknotach o nominałach 100 i 20 dolarów ${ }^{63}$; pas nr 2736 - 6 kieszeni i łącznie 57 tys. dolarów w banknotach o nominałach 100, 20 i 10 dolarowych ${ }^{64}$; pas nr 2738 - 5 kieszeni i łącznie 59 tys. dolarów w banknotach o nominałach 100, 20 i 5 dolarów ${ }^{65}$. Jak wynikało z zestawienia depeszy z 30/31 VII 1942 r. oraz protokołu odbioru pieniędzy z 23 IV 1942 r., brakowało dwóch paczek z dolarami: a) jednej paczki z zawartością 200 banknotów o nominałach 100 dolarów i 100 banknotów o nominałach 20 dolarów; b) jednej paczki z zawartościa 300 banknotów o nominałach 20 dolarów ${ }^{66}$.

21 V 1942 r. „Broniwój” polecił „Babiniczowi” i „Ostoi” niejawną obserwację chłopów i członków drużyny szturmowej celem wykrycia wśród nich sprawcy zagarnięcia brakującej sumy dolarów ${ }^{67}$. 9 VII 1942 r., w związku z grożąca „wsypa” na terenie placówki „Kopyto” i koniecznością zlikwidowania tam konfidenta gestapo, „Broniwój” otrzymał polecenie zawieszenia postępowania do odwołania. 12 IX 1942 r. „Broniwój” próbował nawiązać kontakt z placówką AK celem podjęcia zawieszonego postępowania, lecz wszelkie znane mu kontakty były nieaktualne ${ }^{68}$.

${ }^{59}$ Ibidem, Odpis depeszy nr 1751 z 3/7 IV 1942 r., k. 66.

${ }^{60}$ Ibidem, Notatka urzędowa Z. Orlińskiego „Broniwoja” z 6 VI 1942 r., k. 62.

${ }^{61}$ Pas nr 2729 - zawierał: a) 1 paczkę po 200 banknotów o nominale 50 dolarów i 100 banknotów o nominale 20 dolarów; b) 2 paczki po 300 banknotów o nominale 20 dolarów; c) 1 paczka po 100 banknotów o nominale 20 dolarów i 200 banknotów o nominale 10 dolarów; d) 2 paczki po 300 banknotów o nominale 10 dolarów.

${ }^{62}$ Pas nr 2730 - zawierał: a) 1 paczkę po 100 banknotów o nominale 50 dolarów i 200 banknotów o nominale 20 dolarów; b) 5 paczek po 300 banknotów o nominale 20 dolarów.

${ }^{63}$ Pas nr 2735 - zawierał: a) 3 paczki, z których każda posiadała po 100 banknotów o nominale 100 dolarów i 200 banknotów o nominale 20 dolarów; b) 3 paczki, z których każda posiadała po 300 banknotów o nominale 20 dolarów.

${ }^{64}$ Pas nr 2736 - zawierał: a) 2 paczki, z których każda posiadała po 200 banknotów o nominale 100 dolarów i 100 banknotów o nominale 20 dolarów; b) 1 paczkę po 100 banknotów o nominale 20 dolarów; c) 3 paczki, z których każda posiadała po 300 banknotów o nominale 10 dolarów.

${ }^{65}$ Pas nr 2738 - zawierał: a) 1 paczkę po 200 banknotów o nominale 5 dolarów i 100 banknotów o nominale 20 dolarów; b) 4 paczki po 100 banknotów o nominale 100 dolarów i 200 banknotów o nominale 20 dolarów.

${ }^{66}$ AAN, AK, 203/IX-6, Odpis depeszy nr 3030 z 03/31 VII 1942 r. z obliczeniami „Broniwoja”, k. 66.

${ }^{67}$ Ibidem, Notatka urzędowa Z. Orlińskiego „Broniwoja” z 21 V 1942 r., k. 63.

${ }^{68}$ Ibidem, Notatka urzędowa Z. Orlińskiego „Broniwoja”, k. 67. Prawdopodobnie było to związane z działalnością konfidencką na tym terenie M. Szymańskiego „Relampago”. 
Wyniki obserwacji wskazywały, że po akcji odebrania paczek z dolarami od chłopów brakujaccą sumę przywłaszczył żołnierz placówki „Kopyto”, pchor. sap. Tadeusz Szatkowski „Grom”69. Ponownie przesłuchano „Ostoję”, który wskazał, że „Grom” brał udział w odbieraniu pieniędzy od chłopów. Wśród żołnierzy „Grom” cieszył się dużym zaufaniem. Po odebraniu pieniędzy żołnierze AK celem dotarcia do kwatery musieli przejść $5 \mathrm{~km}$. W marszu szli jeden za drugim i pokonywali m.in. lasek i rzeczkę. Noc była ciemna, a więc warunki do kradzieży sprzyjały. „Grom” przez ponad 3/4 drogi niósł słój z pieniędzmi, który był nakryty tylko papierem. Nie miał więc żadnych trudności z kradzieżą jego zawartości. „Ostoja” niósł zabitą gwoździami skrzynkę z pieniędzmi oraz pistolety. Około 400 m przed domem „Ostoi” „Grom” oddał mu słój z pieniędzmi i poszedł do swojego domu. Pieniądze przeliczały cztery osoby w domu „Ostoi”, bez obecności „Groma”. Chłopi powiedzieli żołnierzom AK, że było 28 paczek z pieniędzmi. W trakcie liczenia okazało się, że paczek jest 27. 28 paczke potraktowano jako uszkodzona. Od „Scevoli” „Ostoja” dowiedział się, że „Grom” wymieniał dolary papierowe. Zaczęto obserwować jego zachowanie i tryb życia. Uderzające było to, że „Grom” zaczą stale wyjeżdżać z miasta. Czynił to rzekomo w celach handlowych. Wyjeżdżał do Lublina, Krakowa i Warszawy, ale nigdy nie chciał „Ostoi” podać, gdzie dokładnie się udaje. Do Końskich wracał jedynie na jeden czy dwa dni w tygodniu. Każdorazowo przybywał w nowym luksusowym ubraniu i wytwornej jedwabnej bieliźnie. Kupił futro, co najmniej 10 nowych ubrań, kosztowny sygnet i aparat „Leica”. Zaczał kupować złoto i brylanty. Po tym fakcie stał się jak na warunki w Końskich „magnatem”, wydawał dużo pieniędzy na kobiety. Podobno również zakupił cegielnię na terenie Lubelszczyzny, o czym powiedział Rożnowskiemu. Nadto nagle „Grom” przerwał pracę organizacyjną i zaczą unikać rodziny „Ostoi” i kolegów z AK. Było to tym bardziej dziwne, że przed przyjęciem zrzutu cichociemnych stale u niej bywał. Wtedy również nigdzie nie wyjeżdżał, nie handlował złotem oraz interesował się zadaniami w AK. Wcześniej „Grom” pracował w młynie i handlował mąka. Zdaniem „Ostoi” przez kilka miesięcy pracy „Grom” mógł zarobić łącznie nie więcej niż 10-12 tys. zł. Nie posiadał

69 Tadeusz Szatkowski „Grom” (ur. 9 X 1920 r. w Końskich) był podchorążym z I roku Szkoły Podchorążych Saperów. Wchodził w skład grupy konspiracyjnej obwodu koneckiego ZWZ utworzonej przez hubalczyka Franciszka Głowacza „Lisa”. Następnie był członkiem grupy specjalnej podległej pchor. Stanisławowi Białeckiemu „Scevoli”, zajmujaccej się, od jesieni 1940 r., wyszukiwaniem miejsc na zrzutowiska i lądowiska na terenie obwodu oraz służba ochronna przy komendancie obwodu koneckiego ZWZ. Od kwietnia 1940 r. był adiutantem komendanta placówki miejskiej ZWZ-AK w Końskich Bolesława Czerwińskiego „Kaliny”, „Wira”. Został aresztowany przez gestapo w nocy z 1 na 2 XI 1942 r. i wraz z innymi aresztowanymi członkami AK osadzony w areszcie w Końskich. W nocy 3 XI 1942 r. areszt został opanowany przez żołnierzy AK pod dowództwem pchor. lot. Zygmunta Wyrwicza „Cumulusa”, zaś aresztowani uwolnieni. J.Z. Wroniszewski, op. cit., s. 29, 35; B. Czerwiński „Kalina”, „Wir”, op. cit., s. 63. 
również żadnego majątku. Jego ojciec był, jak na stosunki miejscowe, dość zamożnym ogrodnikiem ${ }^{70}$.

„Scevola” zeznał, że na początku lipca 1942 r. jego kolega Jabłoński „Jasieńczuk"71 zapytał go, czy w zrzucie na placówkę nie było dolarów papierowych. „Jasieńczuk” powiedział mu, że osoba o nazwisku Szatkowski wymieniła, przez jego znajomego w Krakowie, 400 dolarów w banknotach o nominałach 100 i 20 dolarów. Banknoty były nowe i miały kolejne numery serii. „Scevola” nie potwierdził informacji o zrzucie, bowiem nie miał do tego upoważnienia. O powyższym poinformował „Ostoję” i „Mściciela”72. Następnie powiedział o tym „Babiniczowi”, który polecił mu sprawdzić powyższe informacje. Ustalono, że Szatkowski mniej więcej miesiąc po kradzieży wymienił u Rożnowskiego 400 dolarów. Dolary były nowe i miały kolejne numery serii. Tłumaczył się, że dolary kupił $\mathrm{w}$ getcie lubelskim. Nadto $\mathrm{w}$ tym samym czasie $\mathrm{u}$ innej osoby wymienił kolejne 100 dolarów w takich samych odcinkach. Dopytywał się również o adresy handlarzy dolarami. Powyższe informacje „Scevola” przekazał „Babiniczowi”. Od tej pory zaczęto obserwować zachowanie „Groma”, o czym już wspominałem. „Scevola” potwierdził fakt, że „Grom” brał udział w akcji odbierania pieniędzy od chłopów, a przez większą część drogi niósł słój z pieniędzmi. Szedł na końcu. Słój odbierany od chłopów był owinięty papierem i przewiązany sznurkiem „na krzyż”. Po jego odniesieniu do domu odkryto, że nie ma na nim sznurka. „Grom” nie brał udziału w przeliczaniu pieniędzy, bowiem żołnierze, oprócz czterech osób, w odległości ok. $500 \mathrm{~m}$ od kwatery poszli do swoich domów ${ }^{73}$.

Ponownie przesłuchany „Babinicz” zeznał, że w połowie lipca 1942 r. referent VI wydziału „Scevola” poinformował go, że jeden z jego znajomych zapytał, go czy czasem na terenie nie było jakiegoś zrzutu i czy nie brakuje z niego dolarów. Wskazano, że Szatkowski wymieniał większe ilości dolarów papierowych. „Scevoli” polecono sprawdzić tę informację. Potwierdzono ja, uzyskując dodatkowo wiedzę, że Szatkowski kupił na Lubelszczyźnie cegielnię. Sprawę przekazano referentowi bezpieczeństwa. Z uwagi na fakt, że referent ten pozostawał na usługach gestapo, sprawy nie wyjaśnił, a spowodował „wsypę" na terenie obwodu AK. W jej wyniku aresztowano m.in. „Babinicza” i „Groma”. Zostali osadzeni w więzieniu, gdzie „Grom” mówił, że jest gotów wykupić się za 100 tys. zł. Dzień po aresztowaniu „Babinicz” i „Grom” zostali uwolnieni. „Grom” wcześniej pracował dla organizacji, a jego ostatnim działaniem było odebranie pieniędzy od chłopów. Po dokonaniu kradzieży odsunął się od pracy konspiracyjnej i zaczął wyjeżdżać w interesach.

\footnotetext{
70 AAN, AK, 203/IX-6, Protokół przesłuchania B. Tworzyańskiego „Ostoi”, k. 68.

${ }^{71}$ Stanisław Białecki wspominał, że był to Jerzy Jabłoński „Jerz”. Relacja Stanisława Białeckiego..., s. 103.

${ }^{72}$ Być może jest nim Jan Franaszczyk „Mściciel”, żołnierz I drużyny II plutonu miejskiego (plutonu 202) w obwodzie koneckim AK. Relacja L. Nowińskiego..., s. 82.

${ }^{73}$ AAN, AK, 203/IX-6, Protokół przesłuchania S. Białeckiego „Scevoli”, k. 69.
} 
Po odbiciu z więzienia „Babinicz” wyznaczył „Gromowi” melinę w Rzucowie pod Chlewiskami ${ }^{74}$.

"Ostroga”, będacy adiutantem komendanta obwodu, zeznał, że „Grom” zaczął prowadzić hulaszczy tryb życia. Wydawał dużo pieniędzy, kupował rzeczy wartościowe i złoto. Między 1 a 15 VIII 1942 r. wyjechał z jakaśs kobieta do Krynicy, prowadząc rozrzutny tryb życia. „Ostroga” w celu ustalenia, czy „Grom” posiada dolary, zwrócił się do Rożnowskiego, utrzymującego z nim kontakty handlowe, z propozycją kupna 2 tys. dolarów. Wówczas Rożnowski powiedział mu, że spóźnił się, bowiem taką sumę posiada jedynie Szatkowski, który właśnie wyjechał. „Ostroga” był również przy rozmowie, w czasie której „Groma” pytano o cegielnię, cenę zakupu, a także skąd wziął pieniądze. Wówczas „Grom” przyznał, że kupił majątek na Lubelszczyźnie, lecz zmieszał się i nie odpowiedział na pozostałe pytania ${ }^{75}$.

„Wir” zeznał, że „Grom” był przez jakiś czas jego adiutantem. Po kradzieży przestał się interesować praca konspiracyjna i został przeniesiony ze stanowiska adiutanta na referenta saperów. Nic jednak na tym stanowisku nie robił. Nie pracował dla organizacji. Przed kradzieżą nie handlował niczym oprócz mąki, za co go wyrzucili z młyna. Potem zaczął handlować i wyjeżdżać. Proponował „Wirowi” zakup materiałów pochodzących, według jego słów, z getta lubelskiego. Mówił, że nabywa złoto, meble i przedmioty wartościowe. „Wir” dowiedział się, że również handluje dolarami ${ }^{76}$.

Po przeprowadzeniu dochodzenia pchor. Zygmunt Orliński „Broniwój”, prokurator wydziału 24-O-B „Syreny”, sporządził akt oskarżenia przeciwko „Gromowi”. Zarzucał mu dokonanie kradzieży pieniędzy, co stanowiło występek z art. $257 \S 1 \mathrm{kk}^{77} \mathrm{i}$ art. $100 \S 1 \mathrm{kk}^{78}$. „Broniwój” wskazywał, że przy zastosowaniu przepisów art. 35 kk, Rozporządzenia Rady Ministrów z dnia 1 IX 1939 r. o wprowadzeniu postępowania doraźnego ${ }^{79}$ i rozkazu nr 958

${ }^{74}$ Ibidem, Zeznanie Mariana Słomińskiego „Babinicza” z 2 XII 1942 r., k. 70.

${ }^{75}$ Ibidem, Zeznanie „Ostrogi” z 8 I 1943 r., k. 71. Nie wiadomo, kim była osoba o pseudonimie Ostroga składająca zeznanie. W tym czasie na terenie Końskich dwie osoby posługiwały się tym pseudonimem: 1. Józef Sapetta „Ostroga”, „Oroński” - od wiosny 1942 r. do maja 1943 r. komendant Podobwodu Końskie; 2. Józef Węgrzyn „Ostroga”. Por. W. Borzobohaty, „Jodta”. Okręg radomsko-kielecki ZWZ-AK, 1939-1945, Warszawa 1984, s. 146, 148.

76 AAN, AK, 203/IX-6, Zeznanie Bolesława Czerwińskiego „Wira” z 7 I 1943 r., k. 72.

${ }^{77}$ Artykuł $257 \S 1 \mathrm{kk} \mathrm{z} 1932$ r.: „Kto zabiera innej osobie cudze mienie ruchome w celu przywłaszczenia, podlega karze więzienia do lat 5 ”.

78 Artykuł $100 \S 1$ kk z 1932 r.: „Kto w czasie wojny działa na korzyść nieprzyjaciela albo na szkodę siły zbrojnej polskiej lub sprzymierzonej, podlega karze więzienia na czas nie krótszy od lat 10 lub dożywotnio".

${ }^{79}$ Rozporządzeniem Rady Ministrów z dnia 1 IX 1939 r. o wprowadzeniu postępowania doraźnego (Dz.U. RP 1939, nr 87, poz. 554) zaczęły obowiązywać z dniem 2 IX 1939 r. na terenie całej Polski przepisy Rozporządzenia Prezydenta RP z dnia 19 III 1928 r. o postępowaniu doraźnym (Dz.U. RP 1928, nr 33, poz. 315). Postępowaniu doraźnemu podlegały m.in. czyny przestępne z art. $100 \S 1$ kk i art. 257 kk z 1932 r. 
Komendanta Sił Zbrojnych w Kraju z 30 X 1941 r. oskarżony podlegał karze śmierci ${ }^{80}$. W treści ww. pisma, oprócz przedstawienia okoliczności faktycznych, „Broniwój” zaznaczył, że oskarżony będąc podchorążym służby stałej, zaprzysiężonym członkiem AK, dopuścił się $\mathrm{z}$ chęci zysku kradzieży pieniędzy Polskich Sił Zbrojnych przeznaczonych na walkę z wrogiem. Czynem tym „rzucił cień na Święte Imię Żołnierza Wolności, stąd niemożliwe jest zastosowanie okoliczności łagodzących" ${ }^{\text {. }}$.

Wydział Bezpieczeństwa i Kontrwywiadu Oddziału II KG AK 3 V 1943 r. wystosował pismo do Komendanta Sił Zbrojnych w Kraju, w którym, załaczając akta dochodzenia, wnoszono o skierowanie sprawy „Groma” do WSS. $5 \mathrm{~V} 1943 \mathrm{r}$. gen. Stefan Rowecki polecił przekazanie sprawy do sądu ${ }^{82} .11 \mathrm{~V}$ 1943 r. prokurator ppłk Konrad Zieliński „Karola” sporządził akt oskarżenia przeciwko plut. pchor. sł. st. Tadeuszowi Szatkowskiemu „Gromowi”, członkowi placówki AK „Kopyto”, który, jak wskazano, ostatnio mieszkał w Rzucowie pod Chlewiskami w powiecie koneckim. Prokurator zarzucał mu, że 21 IV 1942 r. na terenie placówki „Kopyto” w czasie pełnienia przez siebie obowiazków służbowych zabrał, w celu przywłaszczenia, 28 tys. dolarów papierowych stanowiących własność Sił Zbrojnych w Kraju, czym dopuścił się występku przeciwko mieniu określonemu w art. $257 \S 1 \mathrm{kk} \mathrm{z} 1932$ r. ${ }^{83}$ Prokurator wnosił o wymierzenie kary na podstawie art. 6 statutu WSS. Prokurator nie podzielił stanowiska „Broniwoja”, że czyn ten stanowił przestępstwo z art. 100 $\S 1 \mathrm{kk}$, bowiem wyeliminował go w kwalifikacji czynu. W treści ww. dokumentu nie podano, co było tego powodem. W uzasadnieniu aktu oskarżenia prokurator wskazał, że noca 31 III 1942 r. w rejonie placówki „Kopyto” zrzucono desant spadochronowy: 6 skoczków, 4 kontenery i 2 bagażniki. Desant spadł w odległości $6 \mathrm{~km}$ od czuwającej placówki, co spowodowało niemożność zabezpieczenia zrzuconych pieniędzy i sprzętu. Dopiero z nastaniem dnia placówka zabezpieczyła pasy z pieniędzmi i 2 bagażniki. Wobec zbliżania się Niemców członkowie zabrali tylko część pieniędzy. Nie zdołano wziąć 5 pasów z pieniędzmi papierowymi zakopanych na miejscu zrzutu, bowiem w pobliżu

${ }^{80}$ AAN, AK, 203/IX-6, Akt oskarżenia z 17 IV 1943 r. sporządzony przez pchor. Z. Orlińskiego „Broniwoja”, k. 54-55.

81 Ibidem, k. 55.

${ }^{82}$ Ibidem, Pismo C-9 z 3 V 1943 r., k. 53. Kryptonim „C-9” był używany przez Wydział Bezpieczeństwa i Kontrwywiadu Oddziału II KG AK od 1942 r. do wiosny 1943 r. Wydział posługiwał się także kryptonimem „Wd-69”. M. Ney-Krwawicz, op. cit., s. 414.

${ }^{83}$ Akt oskarżenia „Broniwoja” nie został potraktowany jako skarga inicjująca postępowanie przed sądem, ponieważ nie był on prokuratorem uprawnionym do występowania przed WSS KG AK, a tylko akt oskarżenia tego prokuratora inicjował postępowanie przed tym sądem. Taki akt oskarżenia sporządził później „Karola”, prokurator/ sędzia przy WSS KG AK. Akt oskarżenia „Broniwoja” potraktowano więc jako pismo końcowe analizujące materiał zebrany w dochodzeniu. Zgodnie z art. 103 prawa o ustroju sądów wojskowych z 1936 r. (Dz.U. RP 1936, nr 75, poz. 536) każdy prokurator wojskowy był „przypisany” do określonego sądu. Podobną zasadę przyjęto w konspiracyjnym sądownictwie. 
wystawiony był posterunek niemiecki. Dopiero po tygodniu, gdy posterunek został zdjęty przez Niemców, członkowie placówki udali się na miejsce, lecz nie znaleźli zakopanych pieniędzy. Poszukiwania doprowadziły do ustaleń, że pieniądze zabrali chłopi z pobliskiej wsi. W celu odebrania pieniędzy wysłano tam drużynę szturmowa, w której skład wchodził oskarżony. Część oddanych pieniędzy była zapakowana w zapieczętowane paczki, tak jak je zrzucono. Inna część została przez chłopów wyciagnięta z pasów i przełożona do słojów. Te słoje zabrali członkowie drużyny szturmowej. Żołnierze AK nie przeliczali na miejscu pieniędzy. Powyższe wykorzystał oskarżony, który w drodze powrotnej wykradł z niesionego przez siebie słoja 28 tys. dolarów. Przestępstwo zostało ujawnione dopiero tydzień później, gdy otrzymano z Londynu radiogram z wyszczególnieniem sumy. Sprawcy należało więc szukać albo wśród chłopów, albo wśród członków drużyny szturmowej. Poczynione ustalenia wskazywały na fakt, że oskarżony był sprawca przestępstwa. Stwierdzono, że oskarżony, pochodzący ze średnio zamożnej rodziny, do czasu kradzieży prowadził spokojny i zrównoważony tryb życia i pracował w młynie. Miesiąc po dokonaniu przestępstwa wymienił u handlarza 400 dolarów w banknotach o nominałach po 20 i 100 dolarów. Banknoty były zupełnie nowe i zawierały kolejne numery serii. $\mathrm{W}$ tym samym czasie wymienił również kolejne 100 dolarów. Przed dokonaniem przestępstwa oskarżony pracował w oddziale placówki AK i nigdzie nie wyjeżdżał. Potem przerwał pracę organizacyjna w AK i rozpoczął na szeroka skalę handel dolarami, złotem i brylantami. Często wyjeżdżał do Warszawy, Krakowa i Lublina, odwiedzając dom na jeden lub dwa dni w tygodniu. Zaczął nabywać dobra materialne, m.in. kupił 10 garniturów; miał też zakupić cegielnię w Lubelskiem. To zachowanie zwróciło uwage jego kolegów z AK: „Babinicza”, „Wira”, „Ostrogi”, „Scevoli” i „Ostoi”. Świadkowie stwierdzili, że po odebraniu pieniędzy od chłopów oskarżony niósł słój z pieniędzmi przez ok. 3/4 drogi. Oddany żołnierzom AK słój z pieniędzmi był owinięty papierem i przewiązany sznurkiem „na krzyż”. Po przyjściu na kwaterę sznurka na słoju nie zauważono. Przebywający z oskarżonym w więzieniu „Babinicz” zeznał, że „Grom” mówił mu, że jest w stanie dać za swoje zwolnienie 100 tys. zł. Prokurator stwierdzał, że wszystkie te informacje uzyskane od kolegów oskarżonego, nieżywiących do „Groma” żadnych nieprzyjaznych uczuć, wskazywały, że to oskarżony dokonał kradzieży pieniędzy. Do aktu oskarżenia załączono: 1) polecenie Komendanta Sił Zbrojnych w Kraju; 2) protokoły przesłuchania „Babinicza”, „Kostka”, „Wira”, „Jankowskiego”, „Cumulusa”, „Sochy”, „Ostoi”, „Scevoli” „Ostrogi” i chłopów; 3) protokół obliczenia pieniędzy po ich odebraniu od chłopów; 4) odpis depeszy z Londynu ${ }^{84}$.

21 V 1943 r. odbyła się rozprawa WSS przy Komendzie Sił Zbrojnych w Kraju przeciwko Tadeuszowi Szatkowskiemu „Gromowi”. Sprawę

${ }^{84}$ AAN, AK, 203/IX-6, Akt oskarżenia z 11 V 1943 r., k. 51-51a. 
rozpoznawał II komplet sądzący WSS w składzie: przewodniczący ppłk Witold Szulborski „M”, asesorzy płk Stefan Broniowski „Ostoja”85 i płk Stanisław Rostworowski „Odra”"66. Otrzymała sygnaturę K II 2/43. Oskarżony był nieobecny, zaś rozprawa odbyła się niejawnie. Sądowi przedstawiono akt oskarżenia oraz załączone do niego dowody. Sąd potraktował te dowody jako wystarczające do wydania wyroku. Następnie jednogłośnie uznał oskarżonego za winnego zarzucanego mu aktem oskarżenia występku z art. $257 \S 1 \mathrm{kk}$ i na zasadzie art. 6 statutu WSS skazał go na kare śmierci. Na podstawie art. 8 ww. statutu wyrok przedstawiono do zatwierdzenia Komendantowi Sił Zbrojnych w Kraju, a w razie braku jego akceptacji wystapiono o przekazanie sprawy innemu składowi sądu do ponownego rozpatrzenia ${ }^{87}$.

Wyrok został zatwierdzony przez gen. Stefana Roweckiego „Tura” $26 \mathrm{~V}$ 1943 r. poprzez naniesienie ręcznej adnotacji na protokole rozprawy ${ }^{88}$. Tego samego dnia Komendant Sił Zbrojnych w Kraju, w piśmie skierowanym do Komórki Likwidacyjnej, wskazał, że wyrokiem WSS przy Komendzie Sił Zbrojnych w Kraju z 21 V 1943 r. oskarżony został zasądzony na karę śmierci, a wyrok zatwierdzono. „Tur” polecił bezzwłoczne wykonanie kary i zameldowanie o tym sądowi, Komendantowi Sił Zbrojnych w Kraju oraz oddziałowi, w którym służył „Grom”" wyrok do realizacji Wydziałowi Bezpieczeństwa i Kontrwywiadu Oddziału II KG $\mathrm{AK}^{90}$. Na powyższym piśmie 6 IX 1943 r. „Karola” odnotował ponaglenie wykonania kary, co potwierdzało, że do tego czasu wyrok nie został zrealizowany $^{91}$. W odpowiedzi na powyższe 10 IX 1943 r. Wydział Bezpieczeństwa i Kontrwywiadu KG AK, kryptonim „Wd-69”, wskazywał, że w sprawie wykonania wyroku wysłano zapytanie do Wydziału Łączności Operacyjnej Oddziału V KG AK, kryptonim „55/O”92.

W dokumentach sądowych brak informacji, czy wyrok został wykonany i czy odzyskano skradzione pieniądze. Tadeusz Szatkowski „Grom” został ponownie, pod obcym nazwiskiem, aresztowany przez Niemców w maju 1943 r. w Skarżysku i 24 VI 1943 r. wysłany do obozu koncentracyjnego

${ }^{85}$ Pułkownik Stefan Broniowski „Ostoja” był do stycznia 1944 r. szefem Biura Inspekcji Szefostwa Operacji KG ZWZ-AK. M. Ney-Krwawicz, op. cit., s. 117.

${ }^{86}$ Pułkownik Stanisław Rostworowski „Odra” był od maja 1942 r. pełnomocnikiem do spraw scalenia z AK, a następnie inspektorem w Biurze Inspekcji Szefostwa Operacji KG AK. Ibidem, s. 110, 115, 455.

${ }^{87}$ AAN, AK, 203/IX-6, Protokół rozprawy sądowej z 21 V 1943 r., k. 50.

88 Ibidem, k. 50.

89 Ibidem, Pismo gen. S. Roweckiego „Grota” z 21 V 1943 r., k. 48.

${ }_{90}$ Ibidem, Adnotacja ppłk K. Zielińskiego „Karoli” o przekazaniu wyroku do C-9 z dnia 21 VI 1943 r., k. 48.

${ }^{91}$ Ibidem, Adnotacja ppłk K. Zielińskiego „Karoli” z dnia 6 IX 1943 r., k. 48.

${ }^{92}$ Ibidem, Pismo Wd 69 z 10 IX 1943 r., k. 49. Kryptonim „55-O” był używany przez Wydział Łączności Operacyjnej Oddziału V Łączności KG AK od sierpnia 1943 r. M. Ney-Krwawicz, op. cit., s. 411. 
Auschwitz-Birkenau. Tam oznaczono go numerem 125617. Podejmowane próby jego wykupienia $\mathrm{z}$ obozu nie udały się, bowiem został rozpoznany co do tożsamości i zamordowany ${ }^{93}$. Jak wskazywał Jan Wroniszewski, „Grom” został z obozu odesłany do Radomia, gdzie go zamordowano 15 III 1944 r..$^{94}$

Analizując formalnoprawne aspekty postępowania, należy wskazać, że zgodnie $\mathrm{z}$ art. 1 statutu WSS do ścigania przestępstw przewidzianych w obowiązujących przepisach karnych, popełnionych lub usiłowanych przez osoby wojskowe po 4 XII 1939 r., powołano WSS przy Komendzie Sił Zbrojnych w Kraju oraz komendantach okręgów. Właściwości tych sądów podlegały wszystkie sprawy o przestępstwa godzące w bezpieczeństwo Sił Zbrojnych w Kraju ${ }^{95}$. Poza tym podległość członków AK, jako żołnierzy w czynnej służbie wojskowej, orzecznictwu WSS potwierdziły cytowany wyżej rozkaz nr 51 gen. S. Roweckiego oraz rozkaz Naczelnego Wodza nr 2926 z 3 IX 1941 r. ${ }^{96}$ Oskarżony Tadeusz Szatkowski „Grom” był członkiem AK, a więc „osobą wojskową" w rozumieniu art. 1 statutu WSS, co wskazuje, że WSS był właściwy rzeczowo do rozpoznania jego sprawy karnej. Prócz tego, jak już wspomniałem, sprawy dotyczące zrzutów spadochronowych podlegały V Wydziałowi Dowodzenia i Łączności KG AK, a więc uzasadniona była również właściwość WSS przy KG AK do rozpoznania niniejszej sprawy. Zebrane dokumenty świadcza o tym, że dochodzenie, z uwzględnieniem przerwy uniemożliwiającej podjęcie czynności procesowych, trwało od $19 \mathrm{~V} 1942 \mathrm{r} .{ }^{97}$ do 17 IV 1943 r., tego dnia bowiem „Broniwój” sporządził akt oskarżenia ${ }^{98}$. Co prawda statut WSS nie precyzował dokładnie czasu trwania dochodzenia, wskazując w art. 3 , że prokurator „spiesznie przeprowadza dochodzenie”. Z powyższego jednak wynika, że statut akcentował przede wszystkim szybkość prowadzonego dochodzenia. W niniejszym przypadku nie można mówić o zachowaniu odpowiedniej szybkości dochodzenia. Było to jednak usprawiedliwione tym, że „Broniwój” nie mógł skontaktować się z placówką AK z uwagi na „wsypę” organizacyjną na jej terenie. To stanowiło powód zawieszenia sprawy, a w konsekwencji jej przedłużenia i opóźnienia w wydaniu decyzji końcowej przez prokuratora prowadzacego dochodzenie. Okres od przekazania akt dochodzenia zwierzchnikowi

${ }_{93}$ Informacja o więźniu Tadeuszu Szatkowskim, http://auschwitz.org/muzeum/informacjao-wiezniach/ (dostęp: 9 VIII 2017); Księga pamięci. Transporty do KL Auschwitz z Radomia i innych miejscowości Kielecczyzny 1940-1944, t. III, red. nauk. F. Piper, E. Strzelecka, Oświęcim 2006, s. 1244.

${ }_{94}$ Por. B. Kacperski, J.Z. Wroniszewski, op. cit., s. 124 oraz podpis pod zdjęciem przedstawiającym T. Szatkowskiego, wkładka bez strony.

95 AAN, AK, 203/XV-3, Statut Wojskowych Sądów Specjalnych, k. 20. W innych egzemplarzach statutu w art. 1 określenie „Siły Zbrojne w Kraju” zastapiono „Armią Krajowa”. SPP, A.3.3.7, Statut Wojskowych Sądów Specjalnych, k. 22.

96 AAN, AK, 203/I-16, Rozkaz nr 51 z 30 X 1941 r. gen. S. Roweckiego, k. 259.

${ }_{97}$ Ibidem, 203/IX-6, Protokół z 19 V 1942 r., k. 57a.

${ }^{98}$ Ibidem, Akt oskarżenia z 17 IV 1943 r., k. 55. 
sądowemu ${ }^{99}$, sporządzenia aktu oskarżenia przez prokuratora przy WSS przy KG $\mathrm{AK}^{100}$, do rozpoznania sprawy i wydania wyroku ${ }^{101}$ wyniósł łącznie 18 dni. Należy więc uznać, że działania te rozpoczęto, jak na warunki konspiracyjne, bezzwłocznie, stosownie do art. 4 statutu WSS.

Analiza materiału dowodowego wskazuje, że w dochodzeniu podjęto szereg czynności o charakterze procesowym, jak: rozpytanie osób, przesłuchanie świadków, wizja lokalna, sprawdzenie informacji i oględziny sporządzonych dokumentów z odbioru zrzutu. Poza tym prokurator prowadzący dochodzenie dokonał analizy zachowań rozpytywanych i zawarł swoje spostrzeżenia w stosownych notatkach urzędowych. Nie ulega również wątpliwości, że analiza ujawnionych dowodów wskazywała, iż nikt inny niż oskarżony nie mógł ukraść pieniędzy. Świadczyły o tym przede wszystkim okoliczności przenosin pieniędzy, a także późniejsze zachowanie oskarżonego, przedstawiane przez świadków.

Przechodząc do analizy zarzutów i kwalifikacji prawnej czynu opisanego $\mathrm{w}$ akcie oskarżenia i przypisanego oskarżonemu w wyroku sądu, należy wskazać na tożsamość opisu i kwalifikację czynu z art. 257 § 1 kk przyjętego przez prokuratora i sąd. Wydaje się jednak, że właściwy opis czynu „Groma” oddawałoby oskarżenie go z obu przepisów. Taką kwalifikację przyją „Broniwój”. Nie wiadomo, dlaczego „Karola” w sporządzonym akcie oskarżenia zrezygnował z art. $100 \S 1 \mathrm{kk} \mathrm{w}$ kwalifikacji prawnej czynu przestępnego, tym bardziej że w opisie zawarł informację, iż kradzieży dokonano na mieniu Sił Zbrojnych w Kraju. Ewidentnie więc czyn popełniono na szkodę polskiej siły zbrojnej w czasie wojny. Powyższe wskazywał właśnie art. $100 \S 1 \mathrm{kk}$ z 1932 r. Tym bardziej że przestępstwo to zagrożone było karą więzienia na czas nie krótszy niż 10 lat, podczas gdy za czyn z art. $257 \S 1$ kk przewidziano karę do 5 lat więzienia. Czyn z art. $257 \S 1 \mathrm{kk}$ odzwierciedlał działanie oskarżonego co do sposobu działania przestępnego i rodzaju czynu. Jednak nie wskazywał charakteru działania, a więc szkody dla sił zbrojnych i skutków czynu $^{102}$. Stosownie do treści art. 6 statutu WSS sąd mógł orzec karę śmierci w razie stwierdzenia szczególnie niebezpiecznego przestępstwa, które ustawa uznawała za zbrodnię, chociażby w obowiazujacych przepisach nie było ono

${ }_{99}$ Ibidem, Pismo C-9 do gen. S. Roweckiego z 3 V 1943 r., k. 53.

${ }^{100} \mathrm{Z}$ uwagi na to, że zarówno przed II wojną światowa, jak i w czasie okupacji prokurator był przyporządkowany do określonego rodzaju sądu, konieczne okazało się ponowne sporządzenie aktu oskarżenia przez właściwego prokuratora, tj. „Karolę”. „Broniwój” nie był prokuratorem przy WSS przy KG AK i nie mógł skutecznie sporządzać wniosków o rozpoczęcie postępowania przed tym sądem.

101 AAN, AK, 203/IX-6, Protokół rozprawy sądowej z 21 V 1943 r., k. 50.

${ }^{102} \mathrm{~W}$ podobnej sprawie sądowej z sierpnia $1943 \mathrm{r}$., dotyczącej kradzieży pieniędzy na placówce „Trawa”, „Karola” również oskarżył sprawców kradzieży o czyn z art. $257 \S 1 \mathrm{kk}$. Wówczas jednak sąd, pod przewodnictwem W. Szulborskiego, nie podzielił jego stanowiska. Sąd przyjął, że sprawcy popełnili przestępstwo z art. $100 \S 1$ kk. B. Szyprowski, Sprawa kradziėzy..., s. $172-173$. 
zagrożone tą $\mathrm{kara}^{103}$. Co do kwestii możliwości wymierzenia kary śmierci za czyn szczególnie niebezpieczny, stanowiący zbrodnię lub też występek, w dokumentach odnoszących się do sądownictwa podziemnego występuja rozbieżności. Zapisy zezwalające na wymierzenie kary śmierci jedynie za czyn stanowiący zbrodnię zostały ujęte $\mathrm{w}$ treści art. 6 statutu WSS, przechowywanego w SPP w Londynie; dokument ten nie jest jednak opatrzony żadną data ${ }^{104}$. W przesłanym do Londynu, jako załącznik nr 1 do meldunku nr 88, tekście statutu WSS w art. 6 znalazł się jedynie zapis o „szczególnie niebezpiecznym przestępstwie", nie uzależniając kary śmierci od tego, czy przestępstwo stanowiło występek, czy zbrodnię ${ }^{105}$. Podobnie brak jest zapisu dotyczącego zbrodni $\mathrm{w}$ depeszy zawierającej tekst statutu WSS, przesłanej przez komendanta głównego ZWZ do lwowskiego okręgu ZWZ ${ }^{106}$. W zatwierdzonym przez Naczelnego Wodza statucie WSS wprowadzono poprawkę do art. 6, ograniczająca możliwość orzeczenia kary śmierci jedynie do niebezpiecznych przestępstw uznanych ustawowo za zbrodnie ${ }^{107}$. Na dokumencie tym brak daty naniesienia tej poprawki, jednak z pisma płk. M. Protasewicza do Szefa Sądownictwa wynika, że dokument ten wraz z poprawkami otrzymano 4 IX 1942 r. $^{108}$ Statut WSS w brzmieniu przesłanym przez gen. S. Roweckiego w meldunku nr 88 został zatwierdzony przez Naczelnego Wodza 29 I 1942 r. ${ }^{109}$ Jeszcze w październiku 1942 r. gen. „Kalina” zawiadamiał, wobec niemożności pozostawienia podziemnej armii bez wymiaru sprawiedliwości, z uwagi na brak decyzji co do ewentualnych zmian w statucie, że wymiar sprawiedliwości będzie sprawowany na zasadach określonych $\mathrm{w}$ meldunku $\mathrm{nr} 88^{110}$. Co więcej, statut WSS, który w lipcu 1943 r. przesłano Naczelnemu Wodzowi, w art. 6 zawierał zapis pozwalajacy na wymierzenie kary śmierci oskarżonemu winnemu szczególnie niebezpiecznego przestępstwa, którego ustawa nie uznawała za zbrodnię i nie przewidywała takiej kary ${ }^{111}$. Trzeba więc przyjać, że w dacie wydania przez sąd orzeczenia w sprawie „Groma” nie obowiązywał zapis art. 6 statutu WSS dotyczący zbrodni.

${ }^{103} \mathrm{~W}$ art. $32 \S 1$ cytowanego wyżej rozporządzenia o postępowaniu doraźnym z $1928 \mathrm{r}$. możliwość wymierzenia kary śmierci ograniczono do sytuacji, w której sąd jednomyślnie uznał oskarżonego za winnego przestępstwa, za które przewidziana była kara powyżej 5 lat więzienia.

104 SPP, A.3.3.7, Statut WSS, k. 23.

${ }^{105}$ Ibidem, Załącznik nr 1 do meldunku nr 88 - statut WSS, k. 17; AAN, AK, 203/I-16, Statut WSS, k. 256.

106 AAN, AK, 203/XV-3, Statut WSS - załącznik do depeszy nr 26 z 27 XI 1941 r. gen. Stefana Roweckiego „Kaliny” do gen. Kazimierza Sawickiego „Pruta”, k. 20.

${ }^{107}$ SPP, A.3.3.7, Statut WSS, k. 22-24; ibidem, Depesza płk. M. Protasewicza „Rawy” nr 2380/42, zał. 2 - Wojskowe Sądy Specjalne, k. 27.

${ }^{108}$ Ibidem, Pismo L.dz. 79/tj. 42, k. 25.

109 Ibidem, Pismo płk. T. Rudnickiego z 23 III 1942 r., k. 35.

110 Ibidem, Meldunek Nr 157 gen. S. Roweckiego „Kaliny” z 16 X 1942 r., k. 32.

111 Ibidem, Meldunek Nr 207 gen. T. Komorowskiego „Lawiny” z 21 VII 1943 r., k. 81. 
Reasumując powyższe rozważania, należy uznać, że wydanie wyroku skazującego na karę śmierci było słuszne, oparte na wszechstronnej analizie dowodowych okoliczności zdarzenia, zgodne z obowiązującymi w sądownictwie podziemnym AK zasadami.

\section{Streszczenie}

Prezentowany artykuł poświęcony jest przedstawieniu sprawy karnej rozpoznanej przez Wojskowy Sąd Specjalny przy Komendzie Głównej AK, przeciwko pchor. Tadeuszowi Szatkowskiemu „Gromowi, żołnierzowi AK z placówki odbioru zrzutów pod Końskimi, oskarżonemu o przywłaszczenie pieniędzy na szkodę Polskich Sił Zbrojnych. Autor wskazuje i omawia materiał dowodowy zebrany w sprawie, stanowiacy podstawę przeprowadzenia postępowania karnego oraz wydania wyroku i kwestii zwiąanych z brakiem jego wykonania. Ponadto $\mathrm{w}$ artykule podjęto próbę prawnokarnej analizy powyższej sprawy oraz wydanego wyroku, w odniesieniu zarówno do wymogów formalnoprawnych, określonych przez akty prawne (statut WSS, kodeks karny), jak i słuszności wydanego orzeczenia.

\section{Theft of Airdropped Money from the "Kopyto" Post. Criminal Case of the Special Military Court of the Home Army High Command against Officer Cadet Tadeusz Szatkowski aka Grom}

The article is devoted to the presentation of a criminal case examined by the Special Military Court at the Home Army High Command against the Home Army Officer Cadet Tadeusz Szatkowski aka Grom, who served at the post to receive airdrops near Końskie, charged with appropriation of money to the detriment of the Polish armed forces. The author examines the source material on which the criminal case and sentence were based together with questions related to its non-execution. He also attempts to make a legal-criminal analysis of the case and the sentence in relation to both formal and legal conditions, determined by the legal acts (the statute of the Special Military Court and Criminal Code), and appropriateness of the sentence passed on the accused.

\section{Bibliografia}

Bartoszewski W., 1859 dni Warszawy, Kraków 1974.

Bieniecki K., Lotnicze wsparcie Armii Krajowej, Kraków 1994.

Borzobohaty W., „Jodta”. Okreg radomsko-kielecki ZWZ-AK, 1939-1945, Warszawa 1984.

Chlebowski C., Cztery z tysiaca, Warszawa 1981.

Chmielarz A., Koncepcje wykorzystania skoczków spadochronowych na rzecz okupowanego kraju (1939-1940), w: Polskie wojska spadochronowe w II wojnie światowej, red. nauk. J. Zuziak, Warszawa 2012.

Kacperski B., Wroniszewski J.Z., Końskie i powiat konecki 1939-1945, cz. 3: Konspiracja konecka 1939-1945, Końskie 2005.

Kania L., Stownik biograficzny oficerów-audytorów Stużby Sprawiedliwości Wojska Polskiego 1914-1945, cz. 1, „Wojskowy Przegląd Prawniczy” 2003, nr 4.

Kania L., Stużba Sprawiedliwości w Wojsku Polskim 1795-1945. Organizacja, prawo, ludzie, Siedlce 2015. 
Królikowski H.M., O organizacji desantów i wojska spadochronowego w Polsce przed II wojna światowa, „Szkice Podlaskie” 2000, nr 8.

Księga pamięci. Transporty do KL Auschwitz z Radomia i innych miejscowości Kielecczyzny 1940-1944, t. III, red. nauk. F. Piper, E. Strzelecka, Oświęcim 2006.

Kunert A.K., Stownik biograficzny konspiracji warszawskiej 1939-1944, t. I-II, Warszawa 1987. Ney-Krwawicz M., Komenda Gtówna Armii Krajowej 1939-1945, Warszawa 1990.

Rocznik oficerski 1939. Stan na dzień 23 marca 1939, red. R. Rybka, K. Stepan, Kraków 2006. Szyprowski B., Archiwum Wojskowego Sqdu Specjalnego przy Komendzie Gtównej Armii Krajowej jako „środek walki”. Sprawa karna ptk. Konrada Zielińskiego, „Zeszyty Historyczne WiN-u” 2015, nr 42.

Szyprowski B., Kradziė̇ pieniędzy cichociemnych z placówki „Pole” pod Wyszkowem. Wyrok Wojskowego Sadu Specjalnego na Wtadystawa Wysockiego, „Rocznik Wołomiński” 2011, t. VII.

Szyprowski B., Sprawa kradziė̇y pieniędzy cichociemnych z placówki „Trawa” $i$ rozwiazanie jej przez podziemny wymiar sprawiedliwości, „Przegląd Historyczno-Wojskowy” 2015, nr 1. Tucholski J., Cichociemni, Warszawa 1988.

Biog r a m: Bartłomiej Paweł Szyprowski - dr; ukończył Wydział Prawa i Administracji UMCS w Lublinie (1995); uzyskał stopień naukowy doktora na Wydziale Nauk Historycznych i Społecznych Uniwersytetu Kardynała Stefana Wyszyńskiego w Warszawie (2014); obecnie jest pracownikiem wymiaru sprawiedliwości. Autor m.in. publikacji: Sqd Kapturowy przy Komendzie Głównej Zwiazku Walki Zbrojnej w Warszawie (sierpień 1940 r. - listopad 1941 r.). Podziemie w walce ze zdrajcami Rzeczypospolitej (2016), II Inspektorat Zamojski Armii Krajowej 1948-1950 (2017). Zainteresowania badawcze koncentrują się wokół historii sądownictwa podziemnego, podziemia antykomunistycznego oraz represji komunistycznych wobec żołnierzy II konspiracji. E-mail: bszyprowski@o2.pl. 